\title{
Biyoloji Öğretmen adaylarının Biyoloji Eğitimi Laboratuvar Dersine İlişkin Metaforik Algılarının İncelenmesi ${ }^{*}$
}

\author{
DOI: $10.26466 /$ opus.538351 \\ İrem Yücel Cengiz ${ }^{*}$ Gülay Ekici** \\ * Sosyal Güvenlik Kurumu, Kızılay / Ankara / Türkiye \\ E-Posta: iremyuecel1@hotmail.com \\ ORCID: $\quad$ 0000-0001-6441-7866 \\ ** Prof. Dr., Gazi Üniversitesi, Gazi Eğitim Fakültesi, Beşevler / Ankara/ Türkiye \\ E-Posta: gulayekici@yahoo.com \\ ORCID: $\underline{0000-0003-2418-1929}$
}

\section{Öz}

Bu araştırmada, biyoloji öğretmen adaylarının biyoloji eğitimi laboratuvar dersine ilişkin metaforlarının ve görsel imajlarının belirlenmesi amaçlanmıştır. Bu amaç doğrultusunda, öğretmen adaylarının biyoloji eğitimi laboratuvar dersine iliş̧kin oluşturdukları metaforlar ve çizimleri incelenmiştir. Araştırmada, olgu bilim deseni kullanılmıştır. Çalışma grubu 95 biyoloji öğretmen adayından oluşmaktadır. Verilerin toplanmasinda iki bölümden oluşan "Laboratuvar gibidir, çünkü "şeklinde sorulan bir sorunun yanında kavramı çizimleriyle de anlatmaların isteyen bir soru içeren veri toplama formu kullanılmıştır. Veriler içerik analizi yöntemi ile analiz edilmiştir. Veri toplama formunun ilk bölümünde öğretmen adayları tarafından oluşturulan metaforlar ortak özelliklerine göre, ikinci bölümünde ise çizimler benzer özelliklerine göre kategorize edilmiştir. Metaforların ve çizimlerin özellikleri dikkate alınarak metaforlardan 14 kavramsal kategori, çizimlerden ise 4 kavramsal kategori belirlenerek birlikte ele alınmıştır. Belirlenen metafor ve çizim kategorileri, öğretmen adaylarının her kategoride yer alan ifadeleri ve çizimlerinin birbirini tamamlaması, detaylandırması açıklaması ve benzemesi durumlarına göre ilişkilendirilmiş, 37 öğretmen adayının, oluşturdukları metaforu destekleyecek biçimde çizim yaptığı görülmüş̧ür. Öğretmen adaylarının oluşturdukları metaforu destekler nitelikte çizimler yapmaları, oluşturdukları metaforu somutlaştırmak adına görsel imajların şekillendirdiklerini göstermektedir. Bu kapsamda öğretmen adaylarının laboratuvar ile ilgili metaforlarının ve çizimlerinin en fazla "araçgereç" kategorisinde yoğunlaştığı tespit edilmiştir. Araştırma sonunda konuyla ilgili öneriler belirtilmiştir.

Anahtar Kelimeler: Biyoloji Eğitimi, Laboratuvar, Metafor, Çizim tekniğ

\footnotetext{
*Bu çalışma, birinci yazarın "Öğretmen Adaylarının Biyoloji Eğitimi Laboratuvar Dersine Illişkin Metaforları ve Görsel Imajları" başlıklı yüksek lisans tez çalışmasından hazırlanmıştır.
} 


\title{
Investigating Metaphoric Perceptions of Biology Teacher Candidates on Biology Education Laboratory Course
}

\begin{abstract}
In this study, it was aimed to determine the metaphors and visual images of biology teacher candidates for the biology education laboratory course. For this purpose, the metaphors and drawings of biology teacher candidates about the biology education laboratory course were examined. In the study, the phenomenological design was used. The study group consisted of 95 biology teacher candidates. a data collection form that was used to ask "Laboratory is like because ...." them to answer it with their illustrations. A data collection form consisting of two parts was used for data collection. Data were analyzed by content analysis method. In the first part of the data collection form, metaphors were created by teacher candidates based on their common characteristics and in the second part; the drawings were categorized according to their similar features. Considering the characteristics of metaphors and drawings, 14 conceptual categories from metaphors and 4 conceptual categories from drawings were developed and discussed together. The metaphors and drawing categories were correlated with each other according to the statements of teacher trainees in terms of their completeness, detailing and similarity. It was seen that 37 pre-service teachers draw in a way to support the metaphor they created. The pre-service teachers' drawings that support the metaphor they created, show that they shaped their visual images in order to concretize the metaphor they created. In this context, it was determined that the metaphors and drawings of the teacher candidates were mostly concentrated in the "tools category". At the end of the study, suggestions on the subject were mentioned.
\end{abstract}

Keywords: Biology education, Laboratory, Metaphor, Drawing technique 


\section{Giriş}

İlgili literatür incelendiğinde, eski Yunancada Bios: hayat ve Logos: bilim sözcüklerinden oluşan biyoloji terimi canlı bilimi olarak ifade edilmektedir. Biyoloji bilimi; bitkilerin ve hayvanların kökenlerini, dağılımlarını, yapılarını, gelişimlerini, büyümelerini ve üremelerini inceleyen oldukça önemli bir bilim dalıdır (Türk Dil Kurumu [TDK], 2015). Biyoloji, insan dahil tüm canlıları makro boyuttan mikro boyuta kadar, onları etkileyen dinamik olaylarla birlikte inceleyen bir bilim dalıdır. Günlük hayatı etkileyen çeşitli faktörlerin aslında biyolojik kökenli olması, bunların zamanla sorun haline gelmesi ve bu sorunların aşılmasının biyoloji eğitimine bağlı olduğunun fark edilmesi, biyoloji eğitimine verilen önemin artmasını sağlamıştır. Biyoloji eğitimi öğrencilerin vücutlarının işleyişiyle ilgili bilgileri veren, çevreleriyle ilgili temel bilgileri veren ve bu bilgilerle birçok soruna çözüm getirebilme olanağı sağlayan gözardı edilemeyecek kadar önemli bir eğitimdir (Kılıç, 2009).

Biyoloji eğitimi ülkemizde ilköğretimden yükseköğretime, eğitimin tüm kademelerinde farklı dersler altında yer almaktadır. Milli Eğitim Bakanlığınca hazırlığı yapılan Biyoloji Dersi Öğretim Programı'nın genel amaçları ve bu amaçlar doğrultusunda hazırlanan bazı temel beceriler bulunmaktadır. Bu kapsamda bilimsel bilginin alınması ve uygulanması, bilimsel süreç becerilerinin kullanılması, bilim-teknoloji-toplum ilişkisinin algılanması, bilime yönelik tutum ve değerler geliştirebilme, bilimsel bilginin doğasını anlayabilme ve 21. yüzyıl becerileri adı altında verilen bu temel beceriler Biyoloji Dersi Öğretim Programı kapsamında öğrencilere kazandırılmak istenmektedir (MEB, 2013). Bu becerilerin öğrencilere kazandırılabilmesinde, farklı sınıfların ders programlarında yer alan biyoloji dersinin içeriğini oluşturan konuların öğrencilere sınıfta kuramsal olarak, laboratuvarda ise uygulamalı olarak aktarılması oldukça önemlidir. Atasoy (2004), laboratuvar derslerinin; öğrencilerin motor becerileri öğrenmesini, geliştirmesini ve öğrencilerin bilgileri anlamlandırması için tecrübe sağladığını ifade etmektedir. Kreitler ve Kreitler (1974) ise laboratuvarın, kavramlarla ilgili doğrudan tecrübe oluşturmakta ve bu tecrübelerin kavramların anlamlandırılmasında önemli olduğunu ifade etmektedirler. Laboratuvar ortamı, öğrencilere ilk elden öğrenme tecrübeleri kazandırarak, onların motivasyonlarının artmasını sağlayan, bir bilim insanı gibi belli 
bir düzen içerisinde dikkatli çalışabilme alışkanlığı kazanmalarını sağlayan, soyut kavramları somutlaştırmalarında etkili olan ve en önemlisi öğrenciyi merkeze alarak aktif öğrenmeyi sağlayan bir öğrenme ortamıdır (Ekici, 2003; Ekici ve Gökmen, 2012). Laboratuvarda yapılan deneyler, gözlemler, incelemeler ve uygulamalar öğrencinin öğrenme sürecinde aktif olarak yer almasını, bu yönde hitap edilen duyu organı sayısının artmasını, soyut bilgi ve kavramların somutlaştııılmasını, dolayısıyla daha kalıcı öğrenmeyi sağlamakta yardımcı olmaktadır (Kılıç ve Soran, 2011).

Sınıfta anlatılan kuramsal bilgilerin mutlaka laboratuvarda, öğrencilerin öğrenme sürecinde aktif olarak yer alması ve çeşitli yöntemlerin kullanılmasıyla, somutlaştırılması gerekmektedir. Bireyler klasik yöntemlerle birlikte araştırarak, gözlemleyerek, inceleyerek, görerek, deneyerek, yaparak yaşayarak eğitim aldıkları taktirde aldıkları eğitim daha kalıcı hale gelmekte ve fark yaratabilen bireyler olarak yetişmektedirler. Tüm bunları sağlayan laboratuvar tabanlı öğretim öğrencilere farklı düşünme becerileri kazandırken, organizasyon ve pek çok devinimsel beceriler kazandıran ve okul ortamında öğretmen-öğrenci ve öğrenci-öğrenci etkileşimini güçlendirmeyi hedefleyen yaklaşımdır (Ekici ve Gökmen, 2012). İlgili literatürde Ottander ve Grelson (2006), fen eğitim sürecinde laboratuvar uygulamalarının, öğrencilerin kuramsal bilgi kazanmalarında, bilim dallarını algılayabilmelerinde, bilimin doğasını ve bilimsel yöntemlerin kullanılmasıyla ilgili bir bakış açısı geliştirmelerinde çok etkili olduğunu belirtmektedirler. Fen eğitimi altında yer alan biyoloji eğitiminde de laboratuvar çalışmaları sayesinde öğrenciler bilimsel yöntemle ilgili anlayış geliştirmekte, ayrıca problemleri tanımlama, gözlem yapabilme, hipotez kurabilme, deney yapabilme, sonuç çıkarabilme, analiz edebilme, genelleme yapabilme gibi becerileri de kazanmaktadırlar.

Konuların somutlaştırılmasını sağlamada ve öğrenmelerin daha kalıcı hale getirilmesinde kullanılan süreçlerden biri metaforik düşünme sürecidir. Metaforik düşünme süreci, metafor kullanarak düşünme sürecidir. Bu süreç aşağıda belirtilen çeşitli aşamalardan meydana gelmektedir (Sezer'den aktaran Eraslan, 2011):

1. Açıklanması istenilen soyut bir olgunun bulunması,

2. Bu olguyu açıklamak amacıyla kullanılan somut bir olgunun tespit edilmesi ve bu olgunun sözcüklerle ifade edilmesi,

3. Bu iki olgu arasında kurulabilen özel benzeşimler. 
İfade edilen süreç sonunda soyut ve somut olgu arasında bir benzeşme oluşturulmakta ve metafor ortaya çıkmaktadır. Metaforlar bilimsel teorilerin üretilmesine de yardımc olmaktadır (Niebert, Marsch ve Treagust, 2012). Metafor teriminin farklı dillerde pek çok tanımı yapılmakla birlikte, Latin ve Grek dillerinde "metafora" kökünden geldiği ifade edilmektedir. İki birleşik sözcükten oluşan bir ad olup, Meta: öte, aşırı ve Pherein: taş1mak, yüklenmek anlamlarına gelmektedir. İlgili kaynaklarda daha çok söz sanatı olarak ifade edilen metafor, Türkçede "eğretileme" kavramıyla açıklanmaktadır (Salman, 2003). Metaforun özü bir tür şeyi başka bir tür şeye göre anlamlandırmak ve tecrübe kazanmaktır (Lakoff ve Johnson, 2005, s.27). Metaforlar, bireylerin kişisel tecrübelerine göre anlam kazanmaktadır ki bu noktada, metafor kavramını tecrübelerin dili olarak açıklamak konuyu somutlaştırmakta etkili olacaktır (Miller'den aktaran Saban, 2004). Metaforlar, dilimizin önemli bir bölümünü oluşturmakta olup, aynı zamanda düşünce sistemimizin de önemli bir bölümünü oluşturmaktadırlar. Okunan dokümanların etkili bir şekilde değerlendirilmesinde güçlü duygusal tepkileri ortaya çıkarmada ikna edici bir role sahip olduklarından düşünce yapımız ve akıl yürütme sistemimiz üzerinde etkili bir rol oynamaktadırlar (Baş, 2018). Bireyler düşüncelerini ifade ederken soyut kavramlar ile somut kavramlar arasında ilişki kurarak açıklama yapmaya çalışırlar. Var olan bilgileriyle davranışlar ortaya koyan bireyler, soyut ile somut kavramları ilişkilendirerek düşüncelerini ifade ederken metaforik yapılar meydana getirirler. Metaforlar, insanların hayatı, çevreyi, olayları ve nesneleri nasıl gördükleri; farklı benzetmeler kullandıkları bir ifade aracı olarak düşünülmektedir (Cerit, 2008). Arslan ve Bayrakçı (2006) metaforların eğitimsel alanda kullanıldıklarında, anlamayı aktif olarak yapılandıran bir öğrenme yaklaşımı sağladığını belirtmektedirler. Ayrıca bu yaklaşımda öğrencinin daha önceden bilinen bilgi ile yeni bilgi arasındaki benzerlikleri anlamasının, daha sonra ise yeni öğrenilen bilgi ve onun metaforik sunumu arasındaki farklılıkları tanımlayabilmesinin gerekliliği vurgulanmaktadır. Sanchez, Barreiro ve Maojo (2000) metaforların öğrenmeyi anlamlandırmak için çok etkili araçlar olduğunu; yeni bir şey keşfedebilmek için ilk önce bunun hayal edilebilmesi gerektiğini belirtmişlerdir. Metafor, bireylerin kendi dünyalarını anlamalarına ve yapılandırmalarına yönelik güçlü bir zihinsel haritalama ve mo- 
delleme mekanizması olarak, öğrenmeyi kolaylaştırır ve ilk kez karşılaşılan bilgi yapılarının zihinde hızlı bir şekilde özümlenmesine katkı sağlamaktadır (Arslan ve Bayrakçı, 2006).

Öğretmenler de öğretim faaliyetlerinde metaforlardan sıklıkla yararlanmaktadırlar. Çoğu zaman, sınıflarda öğrencilerin anlamakta zorlandıkları kavramları açılayabilmek için metaforlar kullanılmayı tercih etmektedirler (Mahaffy, 2006). Öğrenciler genel olarak fen derslerini soyut kavramlar içermeleri nedeniyle zor olarak değerlendirmekte ve maalesef bu durum ilgi düzeylerinin azalmasıyla sonuçlanmaktadır (Gilbert, 2004) ki bu noktada metaforlar öğrencilerin soyut olarak algıladıkları kavramları daha kolay öğrenmelerinde çok önemli bir yere sahiptir.

Kısaca metafor; öğrenmeyi kolaylaştıran, soyut kavramları somutlaştırmaya yarayan, söylenmek isteneni daha az sözcükle söylemeye olanak tanıyan ve zihinlerdeki resimlerin ortaya çıkarılmasını sağlayan bir araç olarak tanımlanabilir. Shuell (1990) "Eğer bir resim bin kelimeye bedelse, bir metafor da bin resme bedeldir. Çünkü, bir resim sadece statik bir imge sunarken, bir metafor bir olgu hakkında düşünmek için zihinsel bir çerçeve sunmaktadır" ifadesini kullanarak metaforun önemini vurgulamıştır. Bu araştırmada; belirli bir konuyla ilgili, bireylerin zihinlerinde var olan düşünceleri ortaya çıkarmayı sağlayan metaforlar, yine bireylerin zihinlerindeki görsel imajların ortaya çıkarılmasında kullanılan çizimlerle birlikte, öğretmen adaylarının biyoloji eğitimi laboratuvarı ile ilgili düşüncelerini belirlemek amacıyla kullanılmıştır.

Bu çalışmada, metaforlarla birlikte çizimlerin kullanımı da tercih edilmiştir. Çünkü kelimelerin ifade etmekte yetersiz kaldığı durumlarda görsel imajların kullanımı tercih edilebilmektedir. Bireylerin sahip olduğu görsel imajların ortaya çlkarılmasında çizimlerin önemi büyüktür. Anlatım biçimlerinin en güçlü olanlarından biri çizimlerdir. Çünkü bir çizim aracılığıyla binlerce kelimeyle anlatamadığımız iç dünyamızı anlatabiliriz (Arıc1, 2010; Aykaç, 2012; Dove, Everett ve Preece, 1999; Ersoy ve Türkkan, 2010). Shuell (1990) gibi Gan (2008) da çizilen bir resmin binlerce sözcüğe eşdeğer olduğunu ifade etmiştir. Çizimler; kolayca iletişim kurabilmeyi, zihinde yer alan bilgileri karşı tarafa sunabilmeyi, bu bilgileri anlaşılır hale getirerek transfer edebilmeyi sağlar (Aktaran; Cherney, Seiwert, Dickey ve Flichtbeil, 2006). Çizimler; zihinde yer alan ama kelimelerle ifade edilmesi güç olan fikirlerin, kavramların, bilgilerin ortaya çıarılmasında 
veya belli bir konunun anlaşılma düzeyinin belirlenmesi aşamasında sıkça kullanılabilen bir araçtır. Çizimler yoluyla öğrenciler, çocuklar ve yetişkinler sahip oldukları bilgileri ve düşünceleri sözcüklere bağımlı olmadan ifade ederek rahat iletişim kurabilmekte, kendilerine güvenleri artmakta, görüşlerini belli sınırlar içinde özgürce ortaya koyabilmelerinde etkili olan özgür öğrenme ortamları oluşmasında da kullanabilmektedirler (Balım ve Ormanc1, 2012; Chang, 2012).

Backett-Milburn ve McKie (1999) çizim tekniğinin pek çok avantajlı yönlerine vurgu yapmışlardır. Bu noktada çizim tekniği, nitelikli veriler elde edilmesini sağlar, kısa zamanda uygulanabildiğinden kullanışlı olması, anlaşıır olması ve uygulanabilmesinin zorlayıcı olmaması, her yaştaki öğrenci grubuna uygulanmasının kolay olması, hem uygulayıcı açısından hem de katılımcı açısından eğlenceli bir teknik olması sebebiyle tercih edilmektedir. Araştırma verilerinin toplanma sürecinde çizim tekniğinin kullanılması, katılımcıların ortaya çıkartılamamış algı, anlamlandırma ve tutumları hakkında verilerin tespit edilebilmesi yönünde etkilidir (White ve Gunstone, 2000). Bu noktada görüş belirten Atasoy (2004, s.268) çizim tekniğinin, uygulanabilen diğer tekniklere göre daha kısa zamanda uygulanabildiğini ve nitelikli bilgileri kapsamlıca detaylı olarak elde edebilmek için kullanışlı olduğunu vurgulamaktadır.

İlgili literatür incelendiğinde, biyoloji eğitimi laboratuvar dersiyle ilgili hem metaforların hem de çizim tekniğinin ölçme aracı olarak kullanıldığı bir araştırmaya rastlanılamamıştır. Ural ve Başaran Uğur (2018)'un fen öğretmen adaylarının laboratuvar kavramına yönelik metaforik algılarını belirledikleri bir araştırmaya ulaşılmıştır. Diğer taraftan ilgili literatür incelemesinde, fen bilimlerine yönelik çizimlerin ve imajların yer aldığı çalı̧̧malar tespit edilmiş olup (Avc1, 2008; Backett Milburn ve McKie, 1999; Balım ve Ormanc1, 2012; Chang, 2012; Plotz ve Hollenthoner, 2019; Yücel Cengiz ve Ekici, 2016), ancak biyoloji/öğretmen adaylarının fen derslerine yönelik laboratuvar uygulamalarıyla ilgili metaforlarını belirlemeyi amaçlayan sınırlı sayıda nitel çalışmanın bulunduğu tespit edilmiştir (Arık ve Benli Özdemir, 2016; Aykutlu, Bezen ve Bayrak, 2019; Bağ ve Küçük, 2017; Demirci Güler, 2012; Ural ve Başaran Uğur, 2018). Bu sebeple ilgili araştırma sonuçlarının literatüre zengin ve anlamlı veriler kazandıracağı düşünülmektedir. Araştırmanın, biyoloji eğitiminde laboratuvar dersinin öğretmen adayları tarafından nasıl algılandığına ilişkin sonuçlar ortaya 
koyması bakımından önemli olacağı, araştırmadan elde edilen sonuçların biyoloji eğitimi laboratuvar dersi programlarının geliştirilmesi yönünde yapılacak çalışmalara 1şık tutacağı ve biyoloji eğitiminde laboratuvar konusunda yapılacak çalışmalara katkı sağlayarak rehberlik edebileceği ümit edilmektedir.

\section{Araştırmanın amacı}

$\mathrm{Bu}$ araştırmada genel olarak; biyoloji öğretmen adaylarının biyoloji eğitimi laboratuvar dersine ilişkin metaforik algılarının belirlenmesi amaçlanmıştır. Bu amaç yönünde aşağıda yer verilen sorular belirlenmiştir :

- Biyoloji öğretmen adaylarının laboratuvar dersine ilişkin sahip oldukları metaforlar nelerdir?

- Biyoloji öğretmen adaylarının oluşturdukları metaforlar özellikleri bakımından hangi kavramsal temalarda/kategorilerde dağılim göstermektedir?

- Biyoloji öğretmen adaylarının biyoloji eğitimi laboratuvar dersine ilişkin metaforlarına ait kavramsal temalara/kategorilere göre çizim örnekleri nelerdir?

\section{Yöntem}

\section{Araştırma Modeli ve Deseni}

$\mathrm{Bu}$ araştırmada, araştırma modellerinden biri olan nitel araştırma modelinin uygulanması tercih edilmiştir. Nitel araştırmalar, olaylar ve olguları doğal ortamları içinde tümevarımcı bir yaklaşımla tanımlar ve katılımc1ların bakış açılarını anlamaya odaklanır. Bu noktada bu araştırmada katılımcıların görüşlerini detaylıca ifade edebilmelerine imkan sağlayarak bütüncül bir şekilde algıların ortaya çıkmasını sağlaması ve esnek olması gibi sebeplerden dolayı nitel araştırma modelinin kullanımı tercih edilmiştir (Çokluk, Yılmaz ve Oğuz, 2011, s.96). Bu model kapsamında katılımcıların metaforik algılarını belirtebilecekleri bir formla bu sağlanmaya çalışılmıştır. Nitel araştırma modelinde pek çok farklı desen mevcuttur. Araştırmada olgubilim (fenomenoloji) deseni kullanılmıştır. Çünkü olgu- 
bilim deseni, farkında olmamıza rağmen derinlemesine ve ayrıntılı bir şekilde bilgi sahibi olmadığımız olguları konu almaktadır. Çeşitli olmakla birlikte olgular en yakın veya en uzak çevremizde gerçekleşen olaylar, yönelimler, deneyimler, kavramlar, algılar, durumlar vb gibi farklı versiyonlarda etkisini gösterebilmektedir (McMillion, 2000; Patton, 1990; Y1ld1rım ve Şimşek, 2016). Olgubilimin özünü bireylerin tecrübeleri oluşturmaktadır. Olgubilim deseninde araştırmacılar, katılımcıların bireysel tecrübelerini araştırmakta, olgulara yönelik algılarını ve olaylara yükledikleri anlamlara ait verileri analiz etmektedirler. Olgubilim tanımlayıcı niteliğe sahip bir araştırma desenidir. Bu bağlamda genelleme yapmak bir amaç değil, olguları tanımlamak en önemli amaçlardan biridir (Akturan ve Esen, 2008; Patton, 1990). Bu araştırmada ise, biyoloji eğitimi laboratuvar dersine ilişkin görüşler metaforlar yoluyla tespit edilmiştir. Alan yazındaki birçok araştırmada metaforların, algıların belirlenmesinde kullanılabilecek güçlü bir araştırma aracı olduğu belirtilmekte olup (Guerrero ve Villamil, 2002; Inbar, 1996) bu araştırmada da kullanımı sağlanmıştır.

\section{Çalışma Grubu}

Araştırma 2014-2015 yılı bahar yarıyılında hazırlanmıştır. Çalışma grubunu bu yarıyılda Gazi Üniversitesi Gazi Eğitim Fakültesi Ortaöğretim Fen ve Matematik Alanları Eğitimi Biyoloji Eğitimi Anabilim Dalı 1., 3., 4. ve 5. sınıflarında öğrenimine devam eden 95 biyoloji öğretmen adayı oluşturmaktadır. Ancak cevap kağıtlarından 88'i geçerli olarak kabul edilmiştir. Bu noktada 7 cevap kağıdı geçersiz sayılmış olup bu kağıtlarda katılımciların konuyla ilgisi olmayan metaforlar ve bu metaforlara yönelik uygun olmayan açıklama cümleleri yazdıkları belirlenmiştir. Araştırmada amaçlı ölçüt örnekleme yöntemiyle çalışma grubu seçilmiştir. Amaçlı ölçüt örnekleme yöntemiyle çalışma grubu seçilmesindeki kriterler ise; katılımcıların Biyoloji Eğitimi Anabilim Dalına kayıtlı öğrenciler olması, farklı sınıflarda eğitim alıyor olmaları, araştırmacıların kolay ulaşabilirliğinin olması, tüm laboratuvar derslerine katılmış olmaları ...vb şeklinde belirlenmiştir. Nitel araştırma modeli desenlerinden özellikle olgu bilim deseni kullanılan araştırmalarda olguyu açıklayabilecek katılımcıların seçiminin dikkatli yapılması gerekmektedir (Creswell, 2007). Türkiye'deki 
diğer eğitim fakültelerinde de olduğu gibi, 2013-2014 eğitim-öğretim y1lında Gazi Üniversitesi Biyoloji Öğretmenliği bölümüne de öğrenci alınamamıştır. Bu sebepten dolayı çalışma grubunda 2. sınıfta eğitimine devam eden biyoloji öğretmen adayı yer almamıştır.

\section{Veri Toplama Araçları}

Tüm metafor analizi araştırmalarında olduğu gibi bu araştırmada da veriler yarı yapılandırılmış bir formla toplanmıştır. Pishghadam ve Pourali'e (2011) göre metafor araştırmalarında yarı yapılandırılmış soru formu kullanımı en fazla kabul görerek tercih edilen veri toplama araçlarından biridir. Form iki bölümden oluşmaktadır. Formda biyoloji öğretmen adaylarının laboratuvar kavramına ilişkin düşüncelerini, bakış açılarını ve algıların belirlemek amacıyla biyoloji öğretmen adaylarının her birinden " $\mathrm{La}$ boratuvar ...... gibidir, Çünkü........" cümlesini kişisel düşünceleri yönünde tamamlamaları istenmiştir. Bu soru formatında, "gibi" kavramı genellikle "metaforun konusu" ile "metaforun kaynağı" arasındaki ilişkiyi daha net ve açık bir şekilde çağrıştırmak için kullanılmaktadır. Yıldırım ve Şimşek (2016), metaforun kendisinin, tek başına metaforun betimsel ve görsel gücünü yeteri kadar ortaya çıaramayacağını, bunu takiben mutlaka "niçin" veya "neden" sorularının sorulmasının yararlı olacağını belirtmektedirler (Aktaran; Ekici, 2016a,b). Çünkü metaforlar, anlaşılmasında problem yaşanan bir olgunun anlaşılmasında problem yaşanmayan, bize bilindik gelen bir olguyla eşleştirilerek ve benzerlik kurularak açıklanmasıdır (Köklü, 2015).

\section{Örnek:}

\begin{tabular}{ll}
\hline Laboratuvar lego kutusu gibidir. & $\begin{array}{l}\text { Çünkü lego kutusunun içindeki legoları farklı } \\
\text { farklı birleştirip farklı farklı şekiller oluştururuz. }\end{array}$ \\
\hline Metaforun Konusu & Metaforun Kaynağı \\
\hline
\end{tabular}

Formun II. bölümünde ise, biyoloji öğretmen adaylarının laboratuvar kavramının hatırlattıkları kavramları çizerek anlatmalarının istenildiği bir soru yer almaktadır. 


\section{Verilerin Analizi}

Toplanan verilerden metaforların analiz edilmesi yeni olguların ve kavramların anlaşılabilirliğini arttırmak amacıyla da kullanılan etkili bilimsel araştırma yöntemlerinden biridir (Geçit ve Gencer, 2011, s.2). Verilerin analizine başlamadan önce biyoloji öğretmen adaylarının veri toplama kağıtlarına düşüncelerini doğru ve etkili bir şekilde anlatıp-anlatamadıkları tek tek kontrol edilmiş olup veri toplama kağıtları 1'den başlayarak 88'e kadar numaralandırılmıştır. Bu araştırmada sosyal bilimlerdeki nitel araştırmalarda kullanımı tercih edilen veri analiz yöntemlerinden biri olan içerik analizi kullanılmıştır (Bilgin, 2006; Lichtman, 2010). Veri analiz aşamaları aşağıdaki gibi yapılmıştır (Aktaran; Ekici, 2016a,b);

Kağıtların incelenmesi: Katılımcların veri toplama formunu uygun şekilde cevaplayıp-cevaplamadıkları incelenmiştir.

Uygun olmayan kağıtların elenmesi aşamast: Katılımcların veri toplama formunu uygun şekilde cevaplamadıkları belirlenen toplam 7 cevap kağıdı elenmiş̧tir.

Kağıtların tekrar derlenmesi aşaması: Doğru cevaplanmış olan kağıtlar son olarak gözden geçirilmiştir.

Kă̆ıtların sıralanması ve numaralandırılması aşaması: Doğru cevaplanmış olan kağıtlar sıralanmış ve sıra numarası verilmiştir.

Metaforların incelenmesi aşaması: Metaforlar tek tek incelenmiş, metaforun kaynağı ve metaforunun konusu arasındaki uyumun olup-olmadığı incelenmiştir.

Kategorilerin geliştirilmesi aşaması: Belirlenen metaforların dağılım gösterecekleri kategoriler belirlenmiştir. Kategoriler öğretmen adaylarının oluşturdukları metaforun gerekçesini açıklayan "çünkü ..." bölümü dikkate alınarak oluşturulmuştur.

Metaforların kategorilere dă̆ılımı aşaması: Belirlenmiş olan metaforların uygun şekilde metaforun kaynağını baz alarak kategorilere dağılımı yapılmıştır.

Geçerlik ve güvenirlik aşaması: Araştırma sonuçlarının ilgili literatürle karşılaştırılması, katılımcı görüşlerinden alıntılar yapılması, iki uzman sonuçlarının belirlenerek güvenirlik değerinin hesaplanması yapılmıştır. 
Metaforların frekanslarını hesaplanması aşaması: Her bir metaforun genelde ve kategorilere göre dağılımları noktasında frekans değerlerinin hesaplanması yapılmıştır.

Verilerin yorumlanması aşamasıdır: İlgili literatüre ve araştırma sonuçlarına göre verilerin yorumlanması yapılmıştır.

Geçerlik ve güvenirliğin sağlanması süreci; Geçerlik ve güvenirlik aşaması bilimsel çalışmaların önemli bir aşamasıdır. Araştırmanın geçerliğini sağlamak amacıyla üç önemli süreç gerçekleştirilmiştir. Bunlar (Aktaran; Ekici, 2016a,b):

- Verilerin kodlanması, kategorilere göre dağılımının yapılması ve verilerin değerlendirilme süreci detaylı ve kaynaklara atıfta bulunularak sunulmuştur (Hruschka vd., 2004),

- Araştırmada elde edilen kategorileri iyi temsil ederek açıkladığı düşünülen, biyoloji öğretmen adaylarının ilgili metafor kapsamında yaptığı açıklamalarından örnekler seçilerek bulgular ve yorumlar bölümünde örneklendirilmiştir (Yıldırım ve Şimşek, 2016),

- Konuyla ilgili literatür detaylıca analiz edilerek konuyla ilgili olan araştırmalar arasındaki benzerlik ve farklılıkların tespit edilmesi sağlanmaya çalışılmıştır (Ratcliff, 1995).

Çalışmanın veri analizinin güvenirliği Miles ve Huberman (1994) tarafından literatüre kazandırılan formülle hesaplanmıştır. Bu formül aşağıdaki gibi ifade edilmektedir:

[Görüş birliği / (Görüş birliğgi + Görüş ayrılı̆̆ı) x 100]

Kodlayıcılar arasındaki ortalama güvenirlik değeri metaforlar için \%95 ve çizimler için \%100 olarak hesaplanmıştır.

Diğer taraftan bulgular bölümünde öğretmen adaylarının görüşlerinden yapılan alıntılar katılımcı numarası belirtilerek vurgulanmıştır. Örneğin (K88) gibi. Verilerin değerlendirilmesinde Nvivo9.3 ve wordle (http://www.wordle.net/) programlarından yararlanılmıştır.

Araştırma da diğer bir aşamada öğretmen adaylarının çizimleri analiz edilmiştir. Bu noktada katılımcıların çizim kompozisyonları içinde çizdikleri her bir nesne, canll, şekil, somut-soyut her türlü vurgu belirlenmiş ve sonrasında uygun kategorilere dağglımı yapılarak analiz edilmiştir. Verilerin analizinde metafor analizinde kullanılan aşamalar dikkate alınmıştır. 
Son aşamada ise, çizimlerle metaforların ortak kesişme kategorileri belirlenmiştir.

\section{Bulgular ve Yorumlar}

Aşağıda elde edilen verilerin tablolaştırılarak bulguların yorumlanmasına yer verilmiştir.

Biyoloji öğretmen adaylarnın laboratuvar dersine ilişkin sahip olduklarn metaforlara ait bulgular

Tablo 1 incelendiğinde, öğretmen adaylarının laboratuvar dersine ilişkin toplam 88 metafor olmak üzere, 55 farklı metafor oluşturdukları görülmektedir. Oluşturulan metaforların frekans dağılımları incelendiğinde: en sık kullanılan metaforun "mutfak" ( $\mathrm{f}=15)$ olduğu, ikinci sırada "fabrika" $(\mathrm{f}=7)$ metaforunun yer aldığı, bunu "puzzle" ( $\mathrm{f}=4)$ metaforunun izlediğ $\mathrm{i}$ görülmektedir. "Lunapark" ( $\mathrm{f}=3$ ) ve "yemek yapmak" (f=3) metaforlarının ardından "dünya" ( $\mathrm{f}=2)$, "evren" ( $\mathrm{f}=2)$, "hastane" ( $\mathrm{f}=2)$, "kiler" ( $\mathrm{f}=2)$, "kütüphane" ( $\mathrm{f}=2)$ ve "türlü yemeği" $(\mathrm{f}=2)$ metaforları sıralanmaktadır. Sonraki sıralarda ise, frekans değeri 1 olan diğer metaforlar bulunmaktadır. Şekil 1'de de görüldüğü gibi frekans değeri yüksek olan metaforlar büyük puntolarla yazıldığı görülebilirken, en düşük frekansı 1 olan metaforlar ise eşit büyüklükte yazılmışlardır.

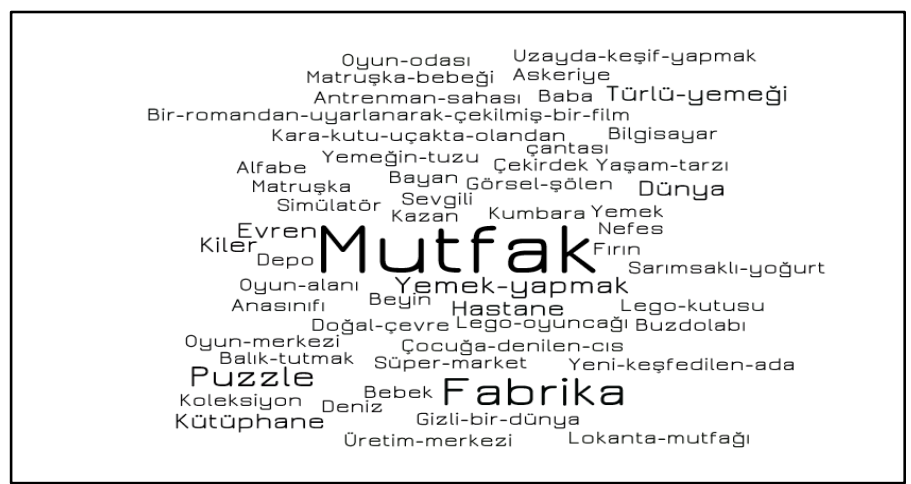

Şekil 1. Biyoloji öğretmen adaylarının laboratuvar kavramına yönelik oluşturdukları metaforları vurgulayan kelime bulutu 
Tablo 1. Öğretmen adaylarının laboratuvar dersine ilişkin oluşturdukları metaforlar

\begin{tabular}{|c|c|c|c|c|c|}
\hline Sira No & Metafor & (f) & Sira No & Metafor & (f) \\
\hline 1. & Mutfak & 15 & 29. & $\begin{array}{l}\text { Düşünceleri karışı in- } \\
\text { sanlar }\end{array}$ & 1 \\
\hline 2. & Fabrika & 7 & 30. & Firın & 1 \\
\hline 3. & Puzzle & 4 & 31. & Gizli bir dünya & 1 \\
\hline 4. & Lunapark (eğlenceli ortam) & 3 & 32. & Görsel şölen & 1 \\
\hline 5. & Yemek yapmak & 3 & 33. & $\begin{array}{l}\text { Kara kutu } \\
\text { (uçakta olan) }\end{array}$ & 1 \\
\hline 6. & Dünya & 2 & 34. & Kazan & 1 \\
\hline 7. & Evren & 2 & 35. & Koleksiyon & 1 \\
\hline 8. & Hastane & 2 & 36. & Kumbara & 1 \\
\hline 9. & Kiler & 2 & 37. & Lego kutusu & 1 \\
\hline 10. & Kütüphane & 2 & 38. & Lego oyuncağ1 & 1 \\
\hline 11. & Türlü yemeği & 2 & 39. & Lokanta mutfağ 1 & 1 \\
\hline 12. & Alfabe & 1 & 40. & Matruşka & 1 \\
\hline 13. & Anasinifi & 1 & 41. & Matruşka bebeği & 1 \\
\hline 14. & Antrenman sahası & 1 & 42. & Nefes & 1 \\
\hline 15. & Askeriye & 1 & 43. & Oyun alanı & 1 \\
\hline 16. & Baba & 1 & 44. & Oyun merkezi & 1 \\
\hline 17. & Balık tutmak & 1 & 45. & Oyun odasi & 1 \\
\hline 18. & Bayan çantası & 1 & 46. & Sarımsaklı yoğurt & 1 \\
\hline 19. & Bebek & 1 & 47. & Sevgili & 1 \\
\hline 20. & Beyin & 1 & 48. & Simülatör & 1 \\
\hline 21. & Bilgisayar & 1 & 49. & Süper market & 1 \\
\hline 22. & $\begin{array}{l}\text { Bir romandan } \\
\text { uyarlanarak } \\
\text { çekilmiş bir film }\end{array}$ & 1 & 50. & $\begin{array}{l}\text { Uzayda keşif } \\
\text { yapmak }\end{array}$ & 1 \\
\hline 23. & Buzdolab1 & 1 & 51. & Üretim merkezi & 1 \\
\hline 24. & Çekirdek & 1 & 52. & Yaşam tarzı & 1 \\
\hline 25. & Çocuğa denilen "cis" & 1 & 53. & Yemeğin tuzu & 1 \\
\hline 26. & Deniz & 1 & 54. & Yemek & 1 \\
\hline 27. & Depo & 1 & 55. & $\begin{array}{l}\text { Yeni } \\
\text { keşfedilen ada }\end{array}$ & 1 \\
\hline \multirow[t]{2}{*}{28.} & Doğal çevre & 1 & & & \\
\hline & & & & Toplam & 88 \\
\hline
\end{tabular}


Biyoloji öğretmen adaylarının laboratuvar kavramı konusunda oluşturduklarn metaforların ortak özellikleri bakımından dağılım gösterdiği kavramsal kategorilere ait bulgular

Biyoloji öğretmen adaylarının laboratuvar dersine ilişkin oluşturdukları toplam 88 metafor, 14 kavramsal kategori altında toplanmıştır. İlgili kategorilere frekanslarının ve metafor sayılarının dağılımına göre Tablo 2'de yer verilirken, yüzdelik dağılımlarına ise Şekil 2'de yer verilmiştir.

Tablo 1. Biyoloji öğretmen adaylarını laboratuvar kavram konusunda oluşturduğu metaforların ortak özellikleri bakımından kategorilere göre dağılımı

\begin{tabular}{|c|c|c|c|}
\hline Kategoriler & $\begin{array}{l}\text { Metafor } \\
\text { Sayı1s1 }\end{array}$ & Metaforlar & (f) \\
\hline Araç - Gereç & 7 & $\begin{array}{l}\text { Mutfak-5, Kiler-2, Fabrika-2, Depo-1, Buzdolab1- } \\
\text { 1, Hastane1-, Süpermarket-1 }\end{array}$ & 13 \\
\hline Üretim Yeri & 6 & $\begin{array}{l}\text { Fabrika-3, Mutfak-3, Yemek yapmak-1, Lokanta } \\
\text { mutfağ1-1, Üretim merkezi-1, Beyin1 }\end{array}$ & 10 \\
\hline $\begin{array}{l}\text { Keşfedilmeyi } \\
\text { Bekleyen }\end{array}$ & 8 & $\begin{array}{l}\text { Evren-2, Lunapark-2, Kara kutu-1, Mutfak-1, } \\
\text { Gizli bir dünya-1, uzayda keşif yapmak-1, Yeni } \\
\text { keşfedilecek ada-1, Sevgili-1 }\end{array}$ & 10 \\
\hline Parçadan Bütüne & 8 & $\begin{array}{l}\text { Puzzle-2, Kazan-1, Lego oyuncağ1-1, Lego ku- } \\
\text { tusu-1, Mutfak-1, Alfabe-1, Kumbara-1, Koleksi- } \\
\text { yon-1 }\end{array}$ & 9 \\
\hline Kapsamlı Olan & 7 & $\begin{array}{l}\text { Kütüphane-2, Matruşka-1, Matruşka bebeği-1, } \\
\text { Dünya-1, Türlü yemeği-1, Doğal çevre-1, Deniz- } \\
1\end{array}$ & 8 \\
\hline Vazgeçilmez Olan & 7 & $\begin{array}{l}\text { Yemek-1, Sarımsaklı yoğurt-1, Çekirdek-1, Baba- } \\
\text { 1, Nefes-1, Yaşam tarzı-1, Yemeğin tuzu-1 }\end{array}$ & 7 \\
\hline $\begin{array}{l}\text { Eğlenceyle } \\
\text { Öğretici Olan }\end{array}$ & 6 & $\begin{array}{l}\text { Lunapark-1, Oyun alanı-1, Oyun odası-1, Ana s1- } \\
\text { nifi-1, Antreman sahas1-1, Yemek yapmak-1 }\end{array}$ & 6 \\
\hline $\begin{array}{l}\text { Dikkat ve Özen } \\
\text { Gerektiren }\end{array}$ & 4 & $\begin{array}{l}\text { Mutfak-1, Bebek-1, Simülatör-1, Düşünceleri ka- } \\
\text { r1ş1k insanlar-1 }\end{array}$ & 6 \\
\hline Kuralları Olan & 5 & $\begin{array}{l}\text { Mutfak-1, Askeriye-1, Fabrrika-1, Hastane-1, Ço- } \\
\text { cuğa denilen "cis"-1 }\end{array}$ & 6 \\
\hline Sabir Gerektiren & 3 & Fırın-1, Puzzle-1, Balık tutmak-1 & 3 \\
\hline Sistemli Olan & 3 & Bilgisayar-1, Fabrika-1, Dünya-1 & 3 \\
\hline $\begin{array}{l}\text { Görselleştirici } \\
\text { Olan }\end{array}$ & 3 & $\begin{array}{l}\text { Oyun merkezi-1, Bir romandan uyarlanarak çe- } \\
\text { kilmiş bir film-1, Görsel şölen-1 }\end{array}$ & 3 \\
\hline Karmaşık Olan & 2 & Türlü yemeği-1, Bayan çantası-1 & 2 \\
\hline \multirow[t]{2}{*}{$\begin{array}{l}\text { Eksiksiz Olması } \\
\text { Gereken }\end{array}$} & 2 & Yemek yapmak-1, Puzzle-1 & 2 \\
\hline & & Toplam & 88 \\
\hline
\end{tabular}


Tablo 2 incelendiğinde, biyoloji öğretmen adaylarının oluşturdukları 88 metaforun ortak kategoriksel özellikleri açısından 14 kavramsal kategori altında dağılım gösterdiği tespit edilmiştir. Kategoriler biyoloji öğretmen adaylarının oluşturdukları metaforun gerekçesini açıklayan "çünkü ..." bölümü dikkate alınarak kategorileştirilmiştir. Bunun nedeni oluşturulan metafor yoluyla ifade edilmek istenilen görüşün metafor toplama formunda "çünkü ..." bölümünde yer almasından kaynaklanmaktadır. Oluşturulan metaforların baba, bebek ve düşünceleri karışık insanlar metaforları hariç diğer tüm metaforların cansız metafor olduğu belirlenmiştir. Kategorilere göre metaforların dağılımı incelendiğinde, en fazla 13 metafor içeren kategorinin olduğu belirlenirken en az metaforun 2 olduğu kategorinin olduğu tespit edilmiştir.

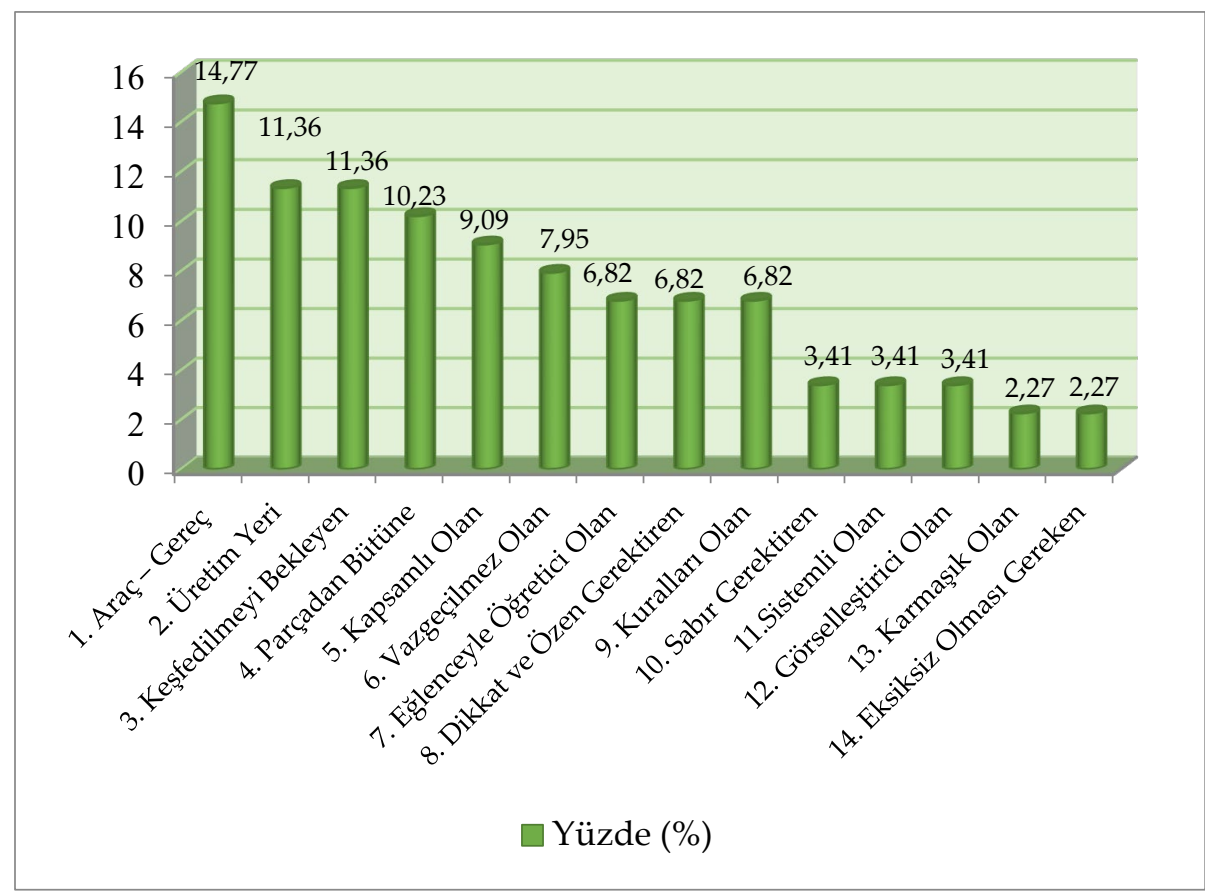

Şekil 2. Biyoloji öğretmen adaylarının oluşturdukları metaforların ortak özellikleri bakımından gruplandırıldığı kategorilere göre yüzdelik dă̆ılımları 
Biyoloji öğretmen adaylarnnın biyoloji eğitimi laboratuvar dersine ilişkin metaforlarna ait kavramsal kategorilere göre çizim örneklerine ait bulgular

Araştırmada biyoloji öğretmen adayları tarafından oluşturulan metaforlar ve çizimler metaforların ortak özellikleri dikkate alınarak geliştirilen 14 kavramsal kategori ile çizimlerin benzer öğeleri dikkate alınarak geliştirilen 4 kavramsal kategori birlikte ele alınmıştır. Her iki bölüm için ayrı ayrı geliştirilen kategoriler birbirini tamamlayan, detaylandıran, açıklayan ve benzeyen bulgularına göre incelenmiş ve bu inceleme sonucunda birbiri ile ilişkili olduğu belirlenen kategorilere Tablo 3'te yer verilmiştir.

Tablo 3. Biyoloji öğretmen adaylarn tarafından oluşturulan metaforlarn ve çizimlerin geliştirilen ortak kategorilere dă̆ılımına göre analizine ilişkin bulgular

\begin{tabular}{|c|c|c|c|c|}
\hline \multirow[b]{2}{*}{ Metafor Kategorileri } & \multicolumn{4}{|c|}{ Çizim Kategorileri } \\
\hline & Araç -Gereç & $\begin{array}{l}\text { Laboratuvar } \\
\text { Çalışmaları }\end{array}$ & $\begin{array}{l}\text { Laboratuvar } \\
\text { Ortamı }\end{array}$ & $\begin{array}{l}\text { Mikroskoptan } \\
\text { Görülenler }\end{array}$ \\
\hline Araç-Gereç & $\checkmark$ & & & \\
\hline Üretim Yeri & & $\checkmark$ & & \\
\hline Keşfedilmeyi Bekleyen & & $\checkmark$ & $\checkmark$ & \\
\hline Parçadan Bütüne & & $\checkmark$ & & \\
\hline Kapsamlı Olan & & $\checkmark$ & & \\
\hline Vazgeçilmez Olan & & $\checkmark$ & $\checkmark$ & \\
\hline Eğlenceyle Öğretici Olan & & $\checkmark$ & & \\
\hline $\begin{array}{l}\text { Dikkat ve Özen } \\
\text { Gerektiren }\end{array}$ & $\checkmark$ & $\checkmark$ & & \\
\hline Kuralları Olan & & $\checkmark$ & $\checkmark$ & \\
\hline Sabır Gerektiren & & $\checkmark$ & & \\
\hline Sistemli Olan & $\checkmark$ & $\checkmark$ & & \\
\hline Görselleştirici Olan & & & & $\checkmark$ \\
\hline Karmaşık Olan & $\checkmark$ & & $\checkmark$ & \\
\hline Eksiksiz Olması Gereken & $\checkmark$ & $\checkmark$ & $\checkmark$ & \\
\hline
\end{tabular}

Tablo 3 incelendiğinde, öğretmen adayları tarafından oluşturulan metaforların ortak özellikleri dikkate alınarak geliştirilen kategorilerin satırlarda, çizilen görsel imajların benzer öğeleri dikkate alınarak geliştirilen kategorilerin ise sütunlarda yer aldığı görülmektedir. Araştırmacılar tarafından belirlenen metafor kategorileri ile çizim kategorilerinin birbiri ile 
ilişkilendirilmesi işlemi öğretmen adaylarının her kategoride yer alan ifadeleri ve çizimleri birbirini tamamlayan, detaylandıran, açıklayan ve benzeyen bulgularına göre incelenerek yapılmıştır. Elde edilen bu sonuçlara göre; 37 öğretmen adayının, oluşturdukları metaforu destekleyecek biçimde çizim yaptığı görülmektedir. Öğretmen adaylarının oluşturdukları metaforu destekler nitelikte çizimler yapmaları, oluşturdukları metaforu somutlaştırmak adına görsel imajlarını şekillendirdiklerini göstermektedir. Elde edilen bu sonuçlara göre, 37 öğretmen adayının, oluşturdukları metaforu destekleyecek biçimde çizim yaptığı görülmektedir. Öğretmen adaylarına ait, metaforu ve çizimi birbirini destekler nitelikte olan metafor, metafor açıklamalarına ve çizimlerin örneklerine aşağıda yer verilmiştir.

\begin{tabular}{|l|l|}
\hline \multicolumn{1}{|c|}{$\begin{array}{l}\text { Kategoriler ve katılımcıların } \\
\text { ifadeleri }\end{array}$} & Kategoriler ve çizim örnekleri \\
ketafor; "Araç - gereç" & $\begin{array}{l}\text { Çizim; "Araç - gereç" kategorisi } \\
\text { "Laboratuvar fabrika gibidir, çünkü } \\
\text { cihazlar bulunmaktadır, laboratu- } \\
\text { varda da sürekli çalışan cihazlar ol- } \\
\text { duğu gibi." (K16). }\end{array}$ \\
$\begin{array}{l}\text { Metafor; "Üretim yeri" kategorisi; } \\
\text { "Laboratuvar üretim merkezi gibi- } \\
\text { dir, çünkü bir sürü malzemeyi bir } \\
\text { araya getirip belirli bir zamanda yeni } \\
\text { şekiller, yeni olaylar meydana getiri- } \\
\text { riz. Kattıklarımızdan tamamen farklı } \\
\text { şeyler de ortaya çıabilir. Eğlenceli ve } \\
\text { güzel bir merkezdir. Bir şey üretir- } \\
\text { ken, bir sürü farklı şeyleri bir araya } \\
\text { getiririz. O yüzden laboratuvar üre- } \\
\text { tim merkezi gibidir." (K87). }\end{array}$
\end{tabular}


Biyoloji Öğretmen adaylarının Biyoloji Eğitimi Laboratuvar Dersine İlişkin Metaforik Algilarının İncelenmesi

Metafor; "Keşfedilmeyi bekle-
yen" kategorisi;
"Laboratuvar kara kutu (uçakta
olandan) gibidir, çünkü dıştan bak-
makla olmaz, yaşamak lazım. İçeri
girdiğinde sıradan bir derslik gibi gö-
rünür, ancak içinde pek çok sır barın-
dırır. Açmadan bilemezsin." (K89)




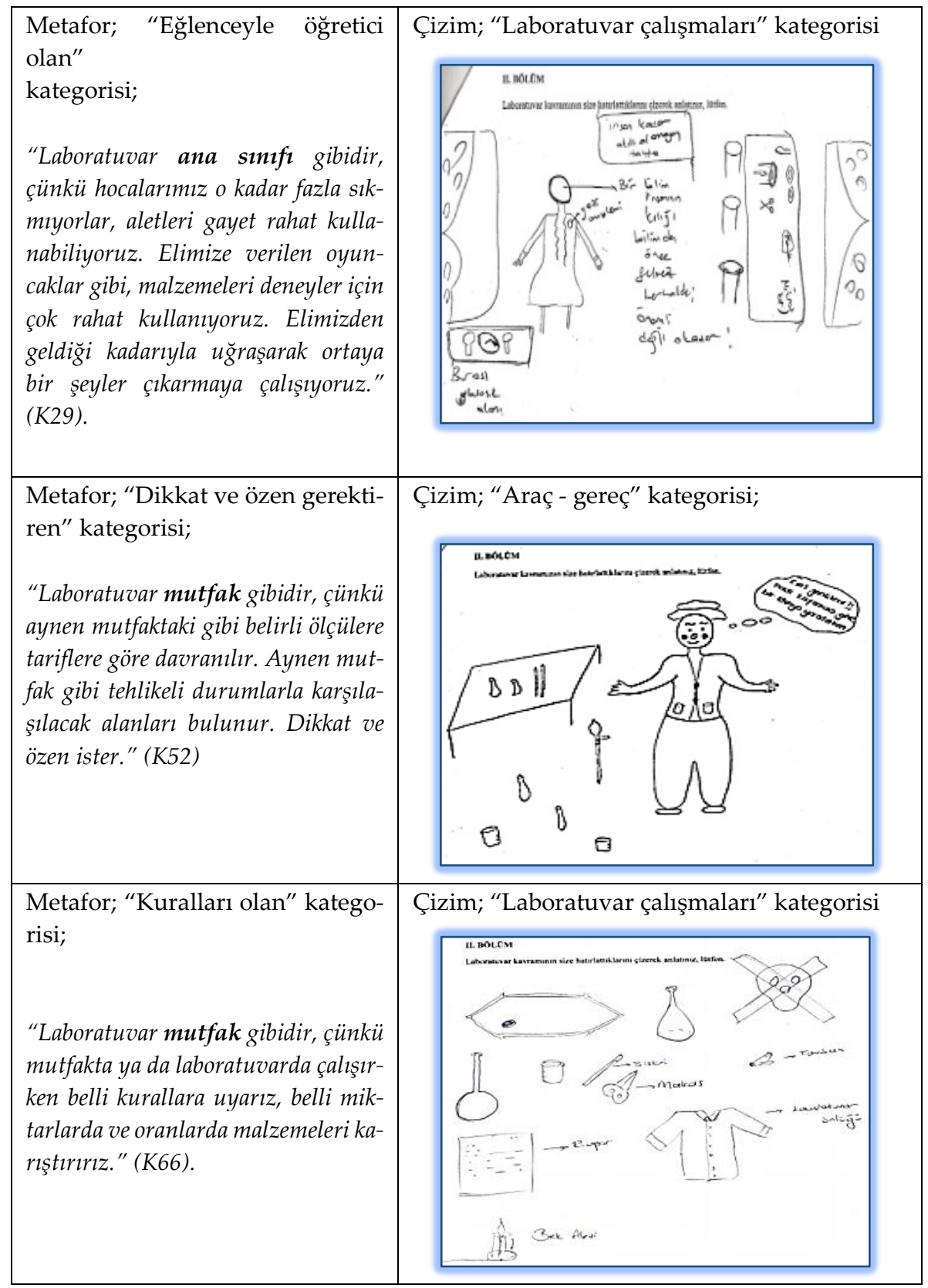




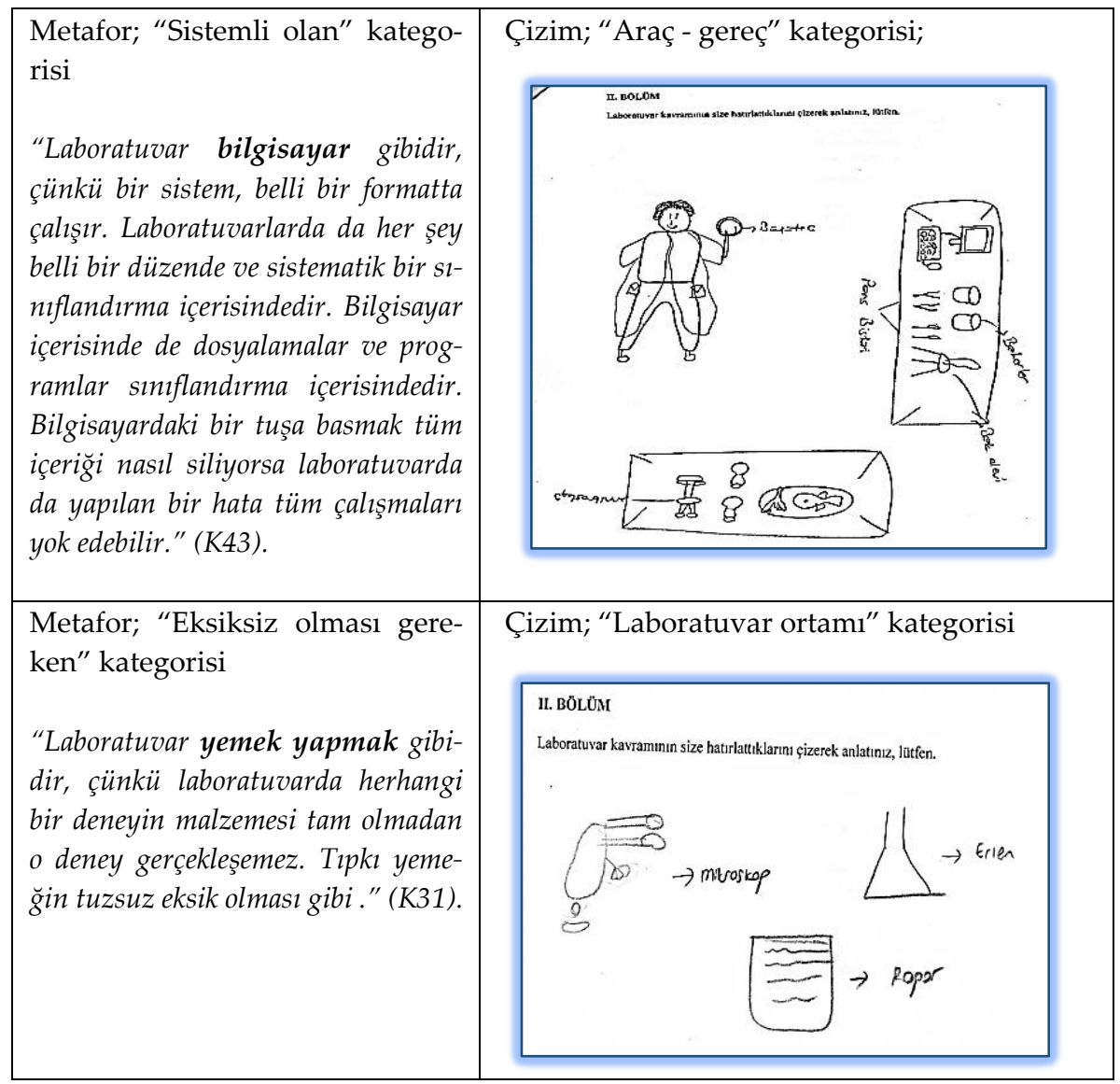

\section{Sonuç, Tartışma ve Öneriler}

Biyoloji öğretmen adaylarının biyoloji eğitimi laboratuvar dersine ilişkin sahip oldukları metaforlarının ve görsel imajlarının belirlenmesinin amaçlandığı bu araştırmada toplam 55 farklı olmak üzere toplam 88 geçerli metafor ifade edildiği belirlenmiştir. Bu metaforların her biri katılımcıların farklı algılarını ifade etmektedir. Metaforlar vurguladıkları ortak özellikleri açısından 14 farklı kavramsal kategori altında gruplandırılmıştır (araçgereç, üretim yeri, keşfedilmeyi bekleyen, parçadan bütüne, kapsamlı olan, vazge- 
çilmez olan, eğlenceyle öğretici olan, dikkat ve özen gerektiren, kurallarn olan, sabır gerektiren, sistemli olan, görselleştirici olan, karmaşık olan ve eksiksiz olması gereken).

Öğretmen adayları kategoriler kapsamında laboratuvar kavramını en fazla frekansa sahip olan "mutfak" metaforu kavramıla açıkladıkları tespit edilmiştir. "Laboratuvar mutfak gibidir, çünkü ..." şeklinde ifade belirten öğretmen adaylarının sayısı oldukça fazladır. Öğretmen adaylarının laboratuvarı mutfak kavramıyla açıklamalarının temel sebeplerinin; laboratuvarın ortamı, kullanılan araç-gereçler veya orada yapılan iş bakımından benzetildiği düşünülmektedir. Bu temel bulgu ilgili literatürde yapılmış olan çalışmalarla benzerlik göstermektedir. Çünkü Arık ve Benli Özdemir (2016) ve Ural ve Başaran Uğur (2018) yaptıkları çalışmalarda laboratuvarın mutfak kavramına benzetildiğini belirlediklerini vurgulamışlardır. Bu durum laboratuvar ve mutfakta genel olarak yapılan işlemlerin (yıkama, kesme, karıştırma, 1sıtma, dondurma vb) benzerlik göstermesiyle ilişki kurulduğunu düşündürmekte olduğunu ifade etmişlerdir.

Belirlenen 14 kategori incelendiğinde, "araç-gereç" kategorisinin, öğretmen adayları tarafindan oluşturulan metaforların yer aldığı en fazla frekans değerine sahip kategori olduğu belirlenmiştir ki, bu frekans değeri toplam metaforlar içerisinde \%14,77'lik bir değere sahiptir. Bu durum öğretmen adaylarının laboratuvar dersine ilişkin algılarının en çok laboratuvarda kullanılan araç-gereçler noktasında toplandığını göstermektedir. Bu kategoride oluşturulan mutfak, kiler, fabrika, depo, buzdolabı, hastane ve süpermarket metaforları ile öğretmen adaylarının laboratuvar konusunda zihinlerindeki şemayı ortaya koymaya çalıştıkları görülmektedir. Öğretmen adaylarının laboratuvarda kullanılan araç-gereçler ile bu kategoride yer alan metaforlarda kullanılan araç-gereçleri birbirine benzettikleri ve işlevsel olarak benzerlik kurdukları görülmektedir.

Metaforlar doğrultusunda geliştirilen "üretim yeri" kategorisinde öğretmen adaylarının laboratuvarı bir şeylerin üretildiği yer olarak düşündükleri görülmektedir. Bu kategoride öğretmen adayları tarafından oluşturulan fabrika, mutfak, yemek yapmak, lokanta mutfağı, üretim merkezi ve beyin metaforları yer almaktadır. Bu durum öğretmen adaylarının zihinlerindeki laboratuvar şemasını, üretim yapılan yer olarak ortaya koymaya çalıştıklarını göstermektedir. Bu kategoride vurgulanan metaforların diğer çalışmalarda da belirtildiği (Arık ve Benli Özdemir, 2016; Ural 
ve Başaran Uğur, 2018) ve ayrıca diğer çalışmalarda genelde olumsuz metaforların (Arık ve Benli Özdemir, 2016; Bağ ve Küçük, 2017; Derman, 2014) belirtildiği vurgulanmaktadır. Ancak bu çalışmada öğretmen adaylarının genelde olumlu metaforlar belirttikleri tespit edilmiştir.

"Keşfedilmeyi bekleyen" kategorisinde öğretmen adayları tarafından oluşturulan evren, lunapark, kara kutu (uçakta olandan), mutfak, gizli bir dünya, uzayda keşif yapmak, yeni keşfedilecek ada ve sevgili metaforları yer almaktadır. Bu kategoride öğretmen adayları laboratuvarda sürekli bir şeyler keşfettiklerini ifade ettikleri ve laboratuvarı keşfedilecek bir yere benzettikleri görülmektedir. Ekici (2010) laboratuvarı öğrencinin merkeze alındığı bir ortam olarak ifade etmiştir. Bu kategoride metafor oluşturan öğretmen adaylarının da laboratuvarda kendilerini merkeze koyarak laboratuvarın keşfedilecek bir yer olduğu yönünde metaforlar oluşturdukları görülebilmektedir. Özellikle lunapark metaforunun belirtilmesi laboratuvar ortamında yapılan etkinliklerin katılımcıları eğlendirmesi yönüne de vurgu yapılmıştır. Arık ve Benli Özdemir de (2016) hazırlamış oldukları çalışmalarında "Eğlenceli Bir Yer Olarak Fen Laboratuvarı" kategorisini elde ettiklerini ve katılımcıların laboratuvar etkinliklerinin eğlendirici yönlerine vurgu yaptıklarını ifade etmişlerdir. Ancak Bağ ve Küçük'ün (2017) yaptığı araştırmada ise, katılımcıların laboratuvarda olmaktan hoşlanmadıkları ve etkinliklerden mutlu olmadıkları sonucunu elde etmişlerdir.

Metaforlar doğrultusunda geliştirilen "parçadan bütüne" kategorisinde öğretmen adayları, laboratuvarda küçük küçük parçaların bir araya getirilmesiyle büyük oluşumların meydana geldiğini ifade etmişlerdir. Bu duruma yönelik olarak öğretmen adaylarının oluşturduğu metaforlar puzzle, kazan, lego oyuncağı, lego kutusu, mutfak, alfabe, kumbara ve koleksiyondur. Ayrıca laboratuvarın yaratıcılığın geliştirilmesine imkan sağlayan bir ortam olduğu yönünde bir vurgu da anlaşılabilmektedir. İlgili literatürde bu kategoriye yönelik bir sonuç olmaması bu çalışmanın orijinal sonuçlarından biri olarak değerlendirilebilir.

"Kapsamlı olan" kategorisinde öğretmen adayları tarafından oluşturulan kütüphane, matruşka, matruşka bebeği, dünya, türlü yemeği, doğal çevre ve deniz metaforları yer almaktadır. Öğretmen adaylarının, labora- 
tuvarın ne kadar kapsamlı, detayları olan ve laboratuvarın geniş yelpazeye sahip bir ortam olduğu yönünde görüşlerinin olduğu anlaşılabilmektedir.

Öğretmen adayları tarafından oluşturulan yemek, sarımsaklı yoğurt, çekirdek, baba, nefes, yaşam tarzı ve yemeğin tuzu metaforları doğrultusunda "vazgeçilmez olan" kategorisi geliştirilmiştir. Bu kategoride yer alan metaforlar ile öğretmen adayları laboratuvarın vazgeçilmez olduğunu ifade etmişler, bu özelliği günlük yaşamlarında vazgeçilmez olduğunu düşündükleri metaforlar aracılığıyla aktarmışlardır. Fen ve biyoloji alanında kalıcı öğrenmelerin gerçekleşebilmesi için laboratuvar kullanımının gerekliliğinin birçok araştırmada ifade edilmiş olması (Akaydın vd., 2000; Akgün, 2008; Demir vd., 2011; Ekici, 2010; Ekici ve Gökmen, 2012; Kılıç ve Soran, 2011), laboratuvarın bir nevi "vazgeçilmez" olduğunu düşündürmüştür ki, buna göre öğretmen adayları tarafından oluşturulan metaforlar literatürde yer alan çalışmalarla benzerlik göstermektedir.

Metaforlar doğrultusunda geliştirilen "eğlenceyle öğretici olan" kategorisinde öğretmen adaylarının laboratuvar ortamını eğlenceyle birlikte öğretici olarak gördükleri belirlenmiştir. Bu kategoride öğretmen adayları tarafından oluşturulan lunapark, oyun alanı, oyun odası, ana sınıfı, antrenman sahası ve yemek yapmak metaforları yer almaktadır. Bu metaforlardan da anlaşılacağı üzere, bu metaforları oluşturan öğretmen adayları için laboratuvar ortamının eğlenceyle öğretici olduğu anlaşılmaktadır. Bu durum öğretmen adaylarının laboratuvar dersinden zevk aldıklarını göstermekte olup ilgili literatürle benzerlik göstermektedir (Arık ve Benli Özdemir, 2016). Ekici de (2010) çalışmasında laboratuvar ortamının öğrencilerin motivasyonunu artırdığını ve öğrenmeyi eğlenceli hale getirdiğini ifade etmiştir.

"Dikkat ve özen gerektiren" kategorisinde öğretmen adayları tarafından oluşturulan mutfak, bebek, simülatör ve düşünceleri karışık insanlar metaforları yer almaktadır. Öğretmen adaylarının bu metaforları oluşturmaları, biyoloji laboratuvarında bu metaforlardaki gibi dikkat ve özen gerektirdiğini düşündüklerini göstermektedir. Akgün (2008) laboratuvar çalışmalarında öğrencilerin sessizliğe, dikkatli olmaya ve temizliğe gerekli itinayı göstermeleri gerektiğini ifade etmiştir. Belirtilen bu metaforları oluşturan öğretmen adaylarının da laboratuvarda çok dikkatli ve özenli olunması gerektiğinin farkında oldukları anlaşılmaktadır. 
Öğretmen adayları tarafından oluşturulan mutfak, askeriye, fabrika, hastane ve çocuğa denilen 'cıs' metaforları doğrultusunda "kuralları olan" kategorisi geliştirilmiştir. Bu kategoride yer alan metaforları oluşturan öğretmen adayları, laboratuvar kurallarını özellik olarak ele almış ve metaforları da buna göre oluşturmuşlardır. Bu durum, öğretmen adaylarının zihinlerinde laboratuvar ile ilgili olarak öncelikle laboratuvar kurallarının yer aldığını göstermektedir.

Metaforlar doğrultusunda geliştirilen "sabır gerektiren" kategorisinde öğretmen adaylarının laboratuvarın sabır gerektiren bir ortam olduğunu düşündükleri görülmektedir. Bu kategoride öğretmen adayları tarafından oluşturulan fırın, puzzle ve balık tutmak metaforları yer almaktadır. Oluşturulmuş metaforlardan da görüleceği üzere öğretmen adayları laboratuvarın sabır gerektiren bir ortam olduğunu düşünmektedirler.

"Sistemli olan" kategorisinde öğretmen adayları tarafından oluşturulan bilgisayar, fabrika ve dünya metaforları yer almaktadır. Öğretmen adaylarının bu metaforları oluşturmaları, laboratuvarın tıpkı oluşturdukları metaforlar gibi belli bir sistemi olduğunu ve sistemli çalıştığını düşündüklerini göstermektedir. Öğretmen adaylarının zihinlerinde laboratuvar ile ilgili sistemli çalışılan bir ortam şeması bulunduğu oluşturulan metaforlardan anlaşılmaktadır.

Öğretmen adayları tarafından oluşturulan oyun merkezi, bir romandan uyarlanarak çekilmiş bir film ve görsel şölen metaforları doğrultusunda "görselleştirici olan" kategorisi geliştirilmiştir. Bu kategoride yer alan metaforları oluşturan öğretmen adaylarının, laboratuvarın bilgileri görselleştirmeye yardımcı ve uygun olan bir ortam olduğunu düşündükleri anlaşılmaktadır. Teorik derslerde öğrenilen bilgilerin ve soyut kavramların laboratuvarda somut hale getirildiği, böylece öğrenilenlerin daha kalıcı hale geldiği bilinmektedir ki, bu kategoride yer alan metaforlar da bu durumu desteklemektedir.

Metaforlar doğrultusunda geliştirilen "karmaşık olan" kategorisinde öğretmen adayları, laboratuvar ortamını karmaşık olarak algıladıklarını ifade etmişlerdir. Bu kategoride biyoloji öğretmen adaylarının oluşturduğu türlü yemeği ve bayan çantası metaforları yer almaktadır. Bu durum, laboratuvar ortamının bazı öğretmen adayları tarafından karmaşık olarak algılandığını göstermektedir. 
"Eksiksiz olması gereken" kategorisinde öğretmen adayları tarafından oluşturulan yemek yapmak ve puzzle metaforları yer almaktadır. Oluşturulmuş metaforlardan da anlaşılacağı üzere öğretmen adayları laboratuvarı zihinlerinde eksiksiz olması gereken bir yer olarak canlandırmaktadırlar. Bu durum öğretmen adaylarının, laboratuvardaki bir eksikliğin sonuca ulaşmayı engelleyeceğini düşündüklerini göstermektedir.

Öğretmen adayları tarafından oluşturulan metaforlar, bu metaforlar doğrultusunda geliştirilen kategoriler ve oluşturulan metaforların geliştirilen kategorilere dağılımı incelendiğinde; öğretmen adaylarının laboratuvar konusunda bilinçli oldukları görülmektedir. Arslan, Bahar ve Özel (2011) laboratuvarda deney sonuçlarını doğru ve güvenilir bir şekilde elde etmek için temiz, dikkatli ve düzenli çalışmanın gerekliliğini vurgulamış ve laboratuvarda kurallara uymanın öneminden bahsetmiştir. Araştırmanın sonuçlarına göre öğretmen adaylarının da laboratuvar kurallarının öneminin bilincinde oldukları; laboratuvarın kendine ait bir düzeni, sistemi, kuralları olduğunu; temiz, dikkatli ve özenli çalışılması gereken bir yer olduğunu metaforlarında ve açıklamalarında ifade ettikleri görülmektedir. Buna göre araştırmanın sonuçları literatürü destekler ve anlamlı bir bütün oluşturur niteliktedir.

Araştırmanın sonuçlarına göre; öğretmen adayları tarafından oluşturulan metaforlar incelendiğinde, öğretmen adaylarının biyoloji laboratuvarı konusunda çoğunlukla olumlu düşüncelere sahip oldukları görülmektedir. Yapıcı (2015), yaptığı çalışmada lise öğrencilerinin biyoloji kavramına ilişkin metaforlarını incelemiş ve çalışma sonucunda öğrencilerin büyük bir çoğunluğunun biyolojiyle ilgili olumlu görüşe sahip olduklarını belirtmiştir. Bu durumdan, öğrencilerin biyolojiyle ilgili sahip oldukları olumlu görüşleri biyoloji laboratuvarına da yansıttıkları sonucuna ulaş1labilir.

Yapılan literatür taraması sonucunda fen ve biyoloji alanında laboratuvar kavramına ilişkin yapılmış çoğu araştırmanın, öğrenci veya öğretmen adaylarının laboratuvar kavramına ilişkin algılarından çok, laboratuvarın kullanımı boyutuyla ilgili olduğu görülmüştür (Akaydın vd., 2000; Bostan Sarıoğlan, 2015; Demir vd., 2011; Ekici ve Gökmen, 2012; Güneş vd., 2013; Kaya, 2001; Kaya ve Gürbüz, 2002; Öztürk Akar, 2006). Bu araştırmalar özellikle fen ve biyoloji alanında laboratuvar kullanımının gerekliliğine vurgu yapmış, bu gerekliliğe rağmen ülkemizdeki laboratuvar 
kullanımı eksikliğinin boyutlarını gözler önüne sermiş ve kullanımdaki eksikliklerin nedenlerini irdelemiştir. Dolayısıyla, biyoloji öğretmen adaylarının biyoloji eğitimi laboratuvar dersine ilişkin sahip oldukları metaforlarının ve görsel imajlarının belirlenmesinin amaçlandığı bu araştırma sonuçlarının literatüre farklı bir bakış açısı kazandıracağı düşünülmektedir.

Biyoloji öğretmen adaylarının laboratuvar kavramına ilişkin çizimleri değerlendirildiğinde orijinal sonuçlar elde edilmiştir. Öğretmen adayları tarafından hazırlanan çizimler arasında çoğunlukla laboratuvarda kullanılan araç-gereçlerin (deney tüpleri, mikroskop, pipet, beher, balon joje, erlen, önlük, etüv, vs.) vurgulandığı belirlenmiştir. Diğer taraftan biyoloji öğretmen adaylarının çizimlerinde pek çok boyutuyla laboratuvar kavramını açıklamaya çalıştıkları belirlenmiştir. Bu noktada; deneylerde kullanılan bitkilere ve hayvanlara ait materyallere (yaprak, çiçek, kurbağa, balık, vs.), laboratuvarda yapılan çalışmalara ait örneklere (masada oturarak deney yapan öğrenci, balık diseksiyonu uygulaması, kalp diseksiyonu uygulaması vb.), mikroskoptan bakıldığında ancak görülebilen bitki ve hayvan hücre şekillerine ait örneklere (hayvan hücresi, yaprak kesiti, bitki hücresi, mikro dünya vb.) ve laboratuvar ortamında yer alan canlı ve cansız nesnelere (masalar, malzemeler, öğrenciler, dolaplar, vs.) yer verildiği tespit edilmiştir.

Ölçme aracında yer alan, biyoloji öğretmen adaylarının "Laboratuvar kavramının size hatırlattıklarını çizerek anlatınız." sorusunu içeren bölümde belirttikleri görüşler değerlendirilmiş, geçerli olarak kabul edilen 86 çizim örneği vurguladığ tegori altında gruplandırılmıştır (Araç-gereç, laboratuvar çalışmaları, laboratuvar ortamı, mikroskoptan görülenler).

Biyoloji öğretmen adaylarının en fazla çizim yaptıkları kategori "araçgereç" kategorisidir. Bu kategorinin frekans değerinin toplam çizimler içerisindeki değeri \%53,49 olarak belirlenmiştir. Bu sonuç biyoloji öğretmen adaylarının eğitimde laboratuvar kavramıyla ilgili olarak en fazla laboratuvarda kullanılan araç-gereçleri hatırladıklarını göstermektedir. Bu kategoride yer alan çizimlerde pipet, lam, lamel, petri kabı, deney tüpleri, mikroskop, balon joje, erlen, beher, önlük, etüv, ısı fırını vb. araç-gereçlerin çizimlerinin yapıldığı görülmüştür. 
Öğretmen adayları tarafından hazırlanan çizimler analiz edilerek oluşturulan bir diğer kategori "laboratuvar çalışmaları" kategorisidir. Bu kategoride yer alan çizimlerde kalp diseksiyonu işlemi, balık diseksiyonu işlemi, çeşitli organların diseksiyonu işlemi yanında masada oturarak deney yapan öğrenciler, laboratuvarda deney yapan bireyler vb. şekilde çizimlerin yapıldığı belirlenmiştir. Öğretmen adaylarının bu çizimleri, laboratuvar kavramının kendilerine laboratuvarda ancak yapılabilen farklı deneyleri ve genel olarak laboratuvarda yapılan çalışmaları hatırlattı̆̆ını göstermektedir. Fen ve Biyoloji alanında laboratuvar çalışmalarının yaparak-yaşayarak öğrenme kapsamında yer alması ve öğrencilere ilk elden aktif öğrenme tecrübeleri sağlaması vurgusuna bağlı olarak (Akaydın vd., 2000; Akgün, 2008; Arslan vd., 2011; Ekici ve Gökmen, 2012), araştırmada öğretmen adaylarının çizimlerinde kendilerini laboratuvarda aktif olarak çalışma yapan öğrenciler olarak çizmiş olmaları, bu çizimlerin literatürde belirtilen bakış açısını destekler nitelikte olduğu noktasına dikkat çekmektedir.

"Laboratuvar ortamı" kategorisinde öğretmen adaylarının çizimlerinde masaların etrafında oturmuş öğrenciler, dolaplar, çeşitli malzemelerle dolu dolaplar, masa ve çeşitli malzemeler gibi laboratuvar ortamının genel olarak dikkat çeken durumunu yansıtan çizimler yer almaktadır. Öğretmen adaylarının çizimleri değerlendirildiğinde görülmektedir ki laboratuvar kavramı kendilerine en çok laboratuvar ortamını, bu ortamda mevcut olan materyalleri vb anımsatmaktadır.

Öğretmen adayları tarafından resmedilen çizimler doğrultusunda geliştirilen diğer bir kategori "mikroskoptan görülenler" kategorisidir. Bu kategoride yer alan çizimlerden öğretmenlerin biyoloji bilimine ait mikro dünyaya odaklandıklarına işaret etmektedir. Bu kategoride öğretmen adayları en fazla mikroskopta hayvan hücresinin, bitki hücresinin, yapraktan alınan bir kesitin vb. yapısına ait görüntüyü resmetmeye çalıştıkları belirlenmiştir. Bu çizimler mikroskoptaki mikro dünyanın öğrencilerin fakında olduklarını ifade etmektedir. Öğretmen adaylarının bu çizimlerinden laboratuvar kavramı ile ilgili olarak öncelikle mikroskoptan gördüklerini hatırladıkları anlaşılmaktadır. Bu kategoride yer alan çizimlerden de görülmektedir ki, fen ve biyoloji alanında laboratuvar çalışmaları yaparak-yaşayarak öğrenme uygulamalarında oldukça etkilidir. Aynı zamanda bireylere ilk elden deneyimler kazandırarak bilgilerin zihinlerdeki 
kalıcılığını artırdığı (Akaydın vd., 2000; Akgün, 2008; Arslan vd., 2011; Ekici ve Gökmen, 2012), bu nedenle öğretmen adaylarının çizimlerine mikroskoptan gördüklerinin yansıdığı düşünülmektedir.

Öğretmen adaylarının çizimlerinin ve çizimlerin yer aldığ 1 kategoriler değerlendirildiğinde; öğretmen adaylarının çoğunluğunun laboratuvarların olmazsa olmazlarından olan araç- gereçlerle ilgili çizimler yaptıkları, bunun yanı sıra laboratuvarlarda yapılan çalışmalara ait çizimler hazırladıkları, bir laboratuvar ortamının nasıl olması gerektiği konusunda bilgi sahibi oldukları ve kendilerini laboratuvarda çalışma yapan bireylerin yerine koyarak çizimler yaptıkları görülmüştür. Ekici ve Gökmen (2012) biyoloji eğitiminde biyoloji laboratuvarının eşsiz bir ortam olduğunu vurgularken, biyoloji eğitiminin laboratuvar çalışmaları, araştırmaları ve deneylerle bütünleştirildiğinde anlam kazandığını ve bu ortamın sahip olduğu olanakların biyoloji dersi öğretim programında belirtilen genel amaçlar ile öğrencilere kazandırılmak istenen temel beceriler doğrultusunda düzenlenmesinin nitelikli biyoloji öğretimi açısından oldukça önemli olduğunu ifade etmişlerdir. Öğretmen adaylarının çizimleri bu yönde literatürle birbirini destekler niteliktedir. Bland (2012), görselliğe dayalı olarak yapılan araştırmaların zengin bir nitel veri kaynağı sunabileceğini ve çizimler aracılığıyla öğrencilerin bakış açılarından onların iç dünyalarının incelenebileceğini ifade etmiştir. Ayrıca Gan (2008) araştırmasında çocukların, çizimleri yoluyla algılayışlarını, düşüncelerini, görüşlerini vb ifade ettiklerini ve bu sayede kendi öğrenmelerini daha kolaylıkla yapılandırabildiklerini vurgulamıştır. Araştırmada çizimler aracılığıyla öğretmen adaylarının iç dünyalarındaki laboratuvar kavramına ilişkin fikirleri ifade edildiği ve bu fikirlerin başarıyla açığa çıkarıldığı düşünülmektedir.

Biyoloji öğretmen adaylarının oluşturduğu metafor ve çizimlerin ortak analizinde elde edilen sonuçlar incelendiğinde; metaforların ortak özellikleri ele alınarak geliştirilen 14 kavramsal kategori ile çizimlerin benzer öğeleri dikkate alınarak geliştirilen 4 kavramsal kategori birlikte ele alınmiştır.

Bu bölümde iki işlem gerçekleştirilmiş ve bu iki işlem birlikte değerlendirilerek bir sonuca ulaşılmıştır. İlk işlemde metaforlar ve çizimler için ayrı ayrı geliştirilen kategoriler birbirlerini tamamlayan, detaylandıran, 
açıklayan ve benzeyen bulgularına göre incelenmiş, bu inceleme sonucunda birbiri ile ilişkili olduğu belirlenen kategoriler ortaya konulmuştur. İkinci işlemde ise, öğretmen adaylarının kâğıtları tek tek incelenerek her bir öğretmen adayının oluşturduğu metaforun yer aldığı kategori ile çiziminin yer aldığı kategori belirlenmiş ve eşleştirilmiştir. Eşleştirme sonucunda frekans tablosu oluşturulmuş ve bu tabloda öğretmen adaylarının frekans dağılımları belirtilmiştir. Yapılan bu işlemlerin ardından sonuca ulaşabilmek için işlemler birlikte değerlendirilmiştir. Değerlendirme sonucunda araştırmacılar tarafından birbiri ile ilişkilendirilen kategorilerde metafor oluşturan ve çizim yapan öğretmen adayları belirlenmiş, bu öğretmen adaylarının frekans değerleri bir tabloyla sunulmuştur. Elde edilen sonuçlara göre 37 öğretmen adayının, oluşturdukları metaforu destekleyecek biçimde çizim yaptığı belirlenmiştir. Hem oluşturduğu metafor hem de çizimi geçerli olarak kabul edilen öğretmen adayı sayısına göre bir değerlendirme yapıldığında 37 öğretmen adayının değeri \%46,84 olarak belirlenmiştir. Araştırmada öğretmen adaylarından oluşturdukları metaforu destekleyecek nitelikte bir çizim yapmaları istenmemesine rağmen sonuçta ortaya çıan bu durumun, öğretmen adaylarının yarıya yakın bir kısmının veri toplama formundaki birinci ve ikinci bölümü bir arada düşündüklerini ve bu iki bölümü birbirini destekleyecek nitelikte cevaplandırdıklarını göstermektedir. Ayrıca bu durum daha güçlü öğrenmenin varlığını ve daha sağlam bir bilişsel yapının oluştuğuna da işaret etmektedir.

\section{Öneriler}

Bu bölümde araştırma sonuçları ve yapılan tartışmalar ışığında sunulan, konuyla ilgili önerilere ve araştırmacılara yönelik önerilere yer verilmiştir.

- Biyoloji eğitiminde laboratuvar derslerinin sadece kuralları olan sıkıcı bir ortam olmadığının gösterilebilmesi ve yaparak yaşayarak öğrenmenin gerçekleşebilmesi için öğretmen adaylarının çalışmalara dâhil edilme sıklığı artırılabilir.

- Her bir eğitim öğretim yılı sonunda öğretmen adaylarından laboratuvar derslerine ilişkin görüş ve öneriler alınabilir. 
- Bu çalışma liselerde yapılarak, üniversite kademesinde elde edilen sonuçlarla ortaöğretim kademesinde elde edilen sonuçların farklılık gösterip göstermediği karşılaştırılabilir.

- Bu çalışma farklı yıllarda farklı öğretmen adayları ile yeniden yapılarak, yıllara göre sonuçlarda bir farklılık olup olmadığı araştırilabilir.

- Metafor ve çizim tekniği dışında farklı yöntem ve teknikler kullanılarak laboratuvar dersine ilişkin görüşlerin belirlenmesine yönelik araştırmalar hazırlanabilir. 
EXTENDED ABSTRACT

\title{
Investigation of Biology Teachers' Teacher Candi- dates Metaphoric Perceptions of Biology Education Laboratory Course
}

\author{
İrem Yücel Cengiz - Gülay Ekici \\ Social Security Institution - Gazi University
}

Metaphors put forward proposals for another way of looking at things and of grasping inchoate intimations of possibilities. They help us to strive better towards grasping the visions and truths and attempting to share in them (Aspin, 1984, p.23). Lakoff and Johnson (2005, p.27) suggest that metaphors are used extensively in everyday life, and that they have an important influence not just on thinking and acting but also on the basis that our conceptual system is metaphorically. For this reason, metaphors that are effective in visualizing and making sense of the external world are often a source of bedside material for education and training purposes.

Metaphorical thinking emphasizes using a situation or an object as a conceptual tool in order to enlighten complex phenomenon or a complex situation (Oxford and others, 1998). By this way, the explanation supports the subject very clearly. Because metaphors enable the process of putting into words of what individual wants to convey as a message without compromising the impression through making it possible to catch affective schemes which are source of strong sensations cannot be uttered (Ortony, 1979, p.45).

In the present study it was aimed to determine the metaphors and visual images of the biology teacher candidates regarding biology education laboratory course. In accordance with this aim, metaphors and drawings of the biology teacher candidates were evaluated. In this regard, these questions have been asked:

1. What are the metaphors that biology teacher candidates have about the concept of biology education laboratory course? 
2. In which conceptual categories those determined metaphors accumulated according to their common features?

3. What are the examples of drawing biology teacher candidates according to conceptual categories of metaphors related to biology education laboratory course?

In this study, phenomenology pattern, one of the qualitative research model which focuses on the facts and events that we are aware of but do not have a deep and detailed understanding, was used to determine the metaphorical thinking situations related to self-perceptions of biology teacher candidates (Yıldırım and Şimşek, 2016). Study group in the study determined with purposeful sampling method. Study group comprised by 95 biology teacher candidates studying in Gazi University Faculty of Education Secondary Education Biology Education Department in 1st, 3rd, 4th and 5th grades in 2014-2015 education year. Criteria such as being volunteer for the study, researcher's accessibility, choosing different grades of Biology Education Department are taken into consideration.

In this study, biology teacher candidates' metaphors about the concept of biology education laboratory lecture have been determined in a semistructured form. Two sectioned data collection form was used for data collecting tool in the study. In first section "Laboratory is like ...., because ......." question is presented while in the second section "Please draw what laboratory concept remembers you" question is presented. A pilot application of the study was conducted with total of 8 biology teacher candidates for identifying the validity and reliability of the prepared measurement tool. Content analysis method was used for evaluating and analyzing the data obtained from the participants. Coefficient of concordance regarding the reliability of the study for experts calculated as \%95 for section one and as $\% 100$ for section two. The reliability of the research has been calculated by the formula of [Consensus / (Consensus + Dissensus) $x$ 100]. Nvivo 9.3 program has been used in data evaluation. For preparing the cloud of words, the wordle program (http://www.wordle.net/) has been used. Obtained data were transposed to tables with descriptive statistics as frequency values and percentile values. Metaphors created by biology teacher candidates in section one are grouped in 14 conceptual categories by considering the shared characteristics. These categories have been ordered according to their inherited metaphor number as follows: "tools, 
equipment, place of production, parts to the whole, comprehensive, indispensable, fun to teach, need attention and care, rules, requiring patience, systematic, visualizer, complex and must be complete".

In this manner, it was found out that metaphors of the teacher candidates related with laboratory are massed on "tools, production place and waiting to be discovered" categories. On the second section of the data collecting form, drawings generated by teacher candidates regarding the laboratory concept are grouped in 4 conceptual categories by considering similar objects. In this manner, it was found that drawings of teacher candidates regarding laboratory concept amassed in "tools and laboratory studies". As common points found by identifying the common parts of the drawings and metaphors created by teacher candidates evaluated, it was observed that 37 of the teacher candidates generated drawings in accordance with supporting the metaphors they generated. In this manner, it was found that metaphors and drawings of the teacher candidates mostly amassed in "tools" category as per their common points.

After the literature analysis, the determination deduced from the results is that teacher candidates develop similar metaphors for the concepts of biology education laboratory course (Arık and Benli Özdemir, 2016; Ural and Başaran Uğur, 2018). This situation shows that biology teacher candidates have similar cognitive structures and they produce their conceptual structures in common schemes.

Also, as Haggis (2004) states, metaphors can be used to shape thinking. The use of metaphors in educational settings allows us to see learning in different dimensions. For this reason, in the process of biology teacher education, biology teacher candidates can develop their thought world by making activities especially for biology teacher candidates to make metaphor in biology education laboratory courses. In this context, the following suggestions can be made:

1. This research can be prepared by the participation of the teachers as well.

2. This research can be supported firstly by interviews and other data gathering methods.

3. Biology teacher training process should be organized in order to turn the metaphors of the biology teacher candidates which con- 
tain negative perceptions towards the biology education laboratory courses into positive ones. At this point, especially the content of applied biology education laboratory courses and its duration can be reviewed and reorganized. In this context, metaphoric perception studies can be performed in the beginning and at the end of the process.

\section{Kaynakça / References}

Akaydın, G., Güler, M.H. ve Mülayim, H. (2000). Liselerimizin biyoloji laboratuvar araç ve gereçleri bakımından durumu. Hacettepe Üniversitesi Ĕ̆itim Fakültesi Dergisi, 19, 1-4.

Akgün, S. (2008). Fen bilgisi öğretiminde laboratuvar kullanımının öğrencilerin başarılarına disiplinler arası etkisi. Yayımlanmamış Yüksek Lisans Tezi, Fen Bilimleri Enstitüsü Kafkas Üniversitesi,Kars.

Akturan, U. ve Esen, A. (2008). Fenomenoloji. (T. Baş ve U. Akturan Ed.) Nitel araştırma yöntemleri içinde (s.83-98). Ankara: Seçkin Yayınc1lik.

Arıcı, B. (2010). Resim, psikoloji ve çocuğun dünyasında resim. Atatürk Üniversitesi Güzel Sanatlar Fakültesi Dergisi, 10, 15-22.

Arık, S. ve Benli, Ö. E. (2016). Fen ve teknoloji öğretmen adaylarının fen laboratuvarına yönelik metaforik algıları. Kastamonu Ĕ̈itim Dergisi, 24(2), 673-688.

Arslan, M. M. ve Bayrakçı, M. (2006). Metaforik düşünme ve öğrenme yaklaşımının eğitim öğretim açısından incelenmesi. Millî Eğitim Dergisi, 171, 100-108.

Arslan, O., Bahar, M. ve Özel, Ç. A. (2011). Genel biyoloji laboratuvar kılavuzu. Ankara: Palme Yayıncilik.

Aspin, D. (1984). Metaphor and meaning in educational discourse. In (W. Taylor Eds.), Metaphors of education (pp. 21-37). London: Heinemann Educational.

Atasoy, B. (2004). Fen öğrenimi ve öğretimi. Ankara: Asil Yayınevi.

Aykaç, N. (2012). İlköğretim öğrencilerinin resimlerinde öğretmen ve öğrenme süreci alg1s1. Eğitim ve Bilim, 37(164), 298-315. 
Avc1, A. (2008). Sinıföğretmenliği öğrencilerinin kendi çizimlerinden fen dersi öğretmenine yönelik algıları ile fen öğretimi öz yeterlik inançları arasındaki ilişki. Yayımlanmamış yüksek lisans tezi. Ege Üniversitesi, Eğitim Bilimleri Enstitüsü, İzmir

Aykutlu, I., Bezen, S. ve Bayrak, C. (2019). An examination of pre-service teachers' metaphorical perceptions concerning physics lab applications. Bartm University Journal of Faculty of Education, 8(1), 32-53

Backett-Milburn, K. ve McKie, L. (1999). A critical appraisal of the draw and write technique. Health Education Research Theory ve Practice, 14(3), 387-398.

Bağ, H. ve Küçük, M. (2017). Pre-service primary school teachers:Images of science laboratory. Route Educational and Social Science Journal, $4(2), 271-285$.

Balım, A.G. ve Ormanc Ü. (2012). İlköğretim öğrencilerinin "maddenin tanecikli yapısı" ünitesine yönelik anlama düzeylerinin çizim yoluyla belirlenmesi ve farklı değişkenlere göre analizi. Ĕğitim ve Ö̆gretim Araştırmaları Dergisi, 1(4), 255-265.

Baş, M (2018). Gazete köşe yazılarında 'demokrasi' kavramına ilişkin metaforlar: Derlem temelli bir eleştirel metafor çözümlemesi. Dil Tarih Coğrafya Fakültesi Dergisi, 58(2), 1390-1411.

Bilgin, N. (2006). Content analysis techniques and case studies in social sciences. Ankara: Siyasal Publication.

Bland, D. (2012). Analyzing children's drawings: applied imagination. International Journal of Research ve Method in Education, 35(3), 235-242.

Bogdan, R.C. ve Biklen, S.K. (2007). Qualitative research for education (5th ed). Boston: Pearson Education, Inc.

Bostan S. A. (2015). Ortaokul öğrencilerinin fen bilimleri dersinde laboratuvar kullanımına ilişkin görüşleri. Eğitim ve Öğretim Araştırmaları Dergisi, 4(4), 333-340.

Cerit, Y. (2008). Öğretmen kavramı ile ilgili metaforlara ilişkin öğrenci, öğretmen ve yöneticilerin görüşleri. Türk Ĕ̆itim Bilimleri Dergisi, 6(4), 693-712.

Chang, N. (2012). What are the roles that children's drawings play in inquiry of science concepts? Early Child Development and Care, 182(5), 621-637. 
Creswell, J.W. (2007). Qualitative inquiry ve research design: Choosing among five traditions. California: SAGE.

Cherney, I.D., Seiwert, C.S., Dickey, T.M. ve Flichtbeil J.D. (2006). Children's drawings: A mirror to their minds. Educational Psychology, 26(1), 127-142.

Çokluk, Ö., Yılmaz, K. ve Oğuz, E. (2011). Nitel bir görüşme yöntemi: Odak grup görüşmesi. Kuramsal Eğitimbilim, 4(1), 95-107.

Demir, S., Böyük, U. ve Koç, A. (2011). Fen ve teknoloji dersi öğretmenlerinin laboratuvar şartları ve kullanımına ilişkin görüşleri ile teknolojik yenilikleri izleme eğilimleri. Mersin Üniversitesi Ĕ̆itim Fakültesi Dergisi, 7(2), 66-79.

Demirci, G.M.P. (2012). Sınıf öğretmeni adaylarının fen ve teknoloji dersine ilişkin metaforik tanımlamaları. Elektronik Sosyal Bilimler Dergisi, 11(41), 53-63.

Derman, A. (2014). Lise öğrencilerinin kimya kavramına yönelik metaforik algıları. Turkish Studies, 9(5), 749-776.

Dove, J.E., Everett, L.A. ve Preece, P.F.W. (1999). Exploring a hydrological concept through children's drawings. International Journal of Science Education, 21(5), 485-497.

Ekici, G. (2003). Öğrencilerin biyoloji laboratuvar derslerinde öğretmenlerinden bekledikleri öğretim yönetimi davranışları. Hacettepe Üniversitesi Ĕ̆itim Fakültesi Dergisi, 25, 68-75.

Ekici, G. (2010). Lise öğrencilerinin biyoloji laboratuvarı sınıf çevresine ilişkin algılarının incelenmesi. NWSA, 5(3), 1092-1106.

Ekici, G. ve Gökmen, A. (2012). Ortä̈ğretim öğrencilerinin biyoloji laboratuvarı sinıf çevresine ilişkin algılarının biyoloji öz-yeterlik algı düzeylerine göre değerlendirilmesi. http://kongre.nigde.edu.tr/xufbmek/ dosyalar/ tam_metin/pdf/2363-30_05_2012-12_48_23.pdf sayfasindan 11.02.2019 tarihinde erişilmiştir.

Ekici, G. (2016a). Öğretmen adaylarının “bilgisayar” kavramına ilişkin metaforik algıları. Gaziantep University Journal of Social Sciences, 15(3), 755-781.

Ekici, G. (2016b). Biyoloji öğretmeni adaylarının mikroskop kavramına ilişkin algılarının belirlenmesi: Bir metafor analizi çalışması. Ahi Evran Üniversitesi Kırşehir Eğitim Fakültesi Dergisi (KEFAD), 17 (1), 615-636. 
Eraslan, L. (2011). Sosyolojik metaforlar. Akademik Bakış Dergisi, 27, 1-22.

Ersoy, A. F. ve Türkkan, B. (2010). İlköğretim öğrencilerinin çizdikleri karikatürlere yansıttıkları sosyal ve çevresel sorunların incelenmesi. Eğitim ve Bilim, 35(156), 96-109.

Gan, Y. (2008). Drawing out ideas: Student-generated drawings' roles in supporting understanding of "light". Ontario Institute for studies in education, University of Toronto. M5S 1V6, Canada.

Geçit, Y. ve Gençer, G. (2011). Sınıf öğretmenliği 1. sınıf öğrencilerinin coğrafya algılarının metafor yoluyla belirlenmesi:Rize Üniversitesi örneği. Marmara Coğrafya Dergisi, 23, 1-19.

Gilbert, J.K. (2004). Models and modelling: Routes to more authentic science education. International Journal of Science and Mathematics Education, 2, 115-130.

Güneş, M.H., Şener, N., Topla,G. N. ve Can, N. (2013). Fen ve teknoloji dersinde laboratuvar kullanımına yönelik öğretmen ve öğrenci değerlendirmeleri. Dicle Üniversitesi Ziya Gökalp Eğitim Fakültesi Dergisi, 20, 1-11.

Guerrero, M.C.M. ve Villamil, O.S. (2002). Metaphorical conceptualizations of ESL teaching and learning. Language Teaching Research, 6 (2), 95-120.

Haggis, T. (2004). Constructions of learning in higher education: Metaphor, epistemology, and complexity. In (J. Satterthwaite \& E. Atkinson Eds.), The disciplining of education: New languages of power and resistance (pp. 181-197). Stoke on Trent: Trentham. 11.02.2019 Tarihinde http://www.wordle.net/ adresinde erişildi.

Inbar, D.E. (1996). The free educational prison: Metaphors and images. Educational Research, 38(1), 77-92.

Kaya, E. (2001). Ortä̈̆gretimde biyoloji öğretiminin yapı ve sorunları:Erzurum örneği. Yayımlanmamış Doktora Tezi. Atatürk Üniversitesi, Fen Bilimleri Enstitüsü, Erzurum.

Kaya, E. ve Gürbüz, H. (2002). Lise ve meslek lisesi öğrencilerinin biyoloji öğretiminin sorunlarına ilişkin görüşleri. Erzincan Eğitim Fakültesi Dergisi, 4(2), 11-21. 
K1lıç, G. (2009). Üniversitelerin eğitim fakültelerinde öğrenim gören biyoloji eğitimi anabilim dalı öğrencilerinin nanobiyoteknoloji eğitimi. Yayımlanmamış Yüksek Lisans Tezi. Gazi Üniversitesi Eğitim Bilimleri Enstitüsü, Ankara.

Kılıç, D.S. ve Soran, H. (2011). Biyoloji laboratuvar uygulamalarma yönelik davranış niyeti anketi. 2nd International Conference on New Trends in Education and their Implications, Antalya.

Köklü, N. (2015). Genel fizik laboratuvarında başarı ve akılda kahıcılık etkilerinin artırlmasına yönelik animasyon, simülasyon ve analojik modellerin geliştirilmesi.Yayımlanmamış Doktora Tezi. Selçuk Üniversitesi, Fen Bilimleri Enstitüsü, Konya.

Kreitler, H. ve Kreitler, S. (1974). The role of experiment in science education. Instructional Science, 3, 75-88.

Lakoff, G. ve Johnson, M. (2005). Metaforlar: Hayat, anlam ve dil ( G. Y. Demir, çev.). İstanbul: Paradigma Yayınları.

Lichtman, M. (2010). Qualitative research in education. Los Angeles: Sage Publications, Inc.

Mahaffy, P. (2006). Moving chemistry education into 3d: A tetrahedral metaphor for understanding chemistry. Journal of Chemical Education, 83(1), 49-55.

Mcmillan, J.H. (2000). Educational research: Fundamentals for the consumer. New York: Longman.

Miles, M.B. ve Huberman, A.M. (1994). Qualitative data analysis. Thousand Oaks, CA: Sage.

Milli Eğitim Bakanlığı (2013). Ortaöğretim biyoloji dersi (9, 10, 11, ve 12. stneflar) öğretim programi 10.02.2019 tarihinde http://ttkb.meb.gov.tr/www/ogretim-programlari/icerik/72 adresinden erişilmiştir.

Niebert, K., Marsch, S. ve Treagust, D.F. (2012). Understanding needs embodiment: A theory-guided reanalysis of the role of metaphors and analogies in understanding science. Science Education, 96(5), 849-877.

Ortony, A. (Ed.). (1979). Metaphor and thought. Cambridge: Cambridge University Press. 
Oxford, R., Tomlinson, S., Barcelos, A., Harrington, C., Lavine, R., Saleh, A. ve Longhini, A. (1998). Clashing metaphors about classroom teachers: Toward asystematic typology for the language teaching field. System, 26, 3-50.

Ottander, C. ve Grelsson, G. (2006). Laboratory work: The teachers' perspective. Journal Biological Education, 40(3), 113-118.

Öztürk, A. E.O. (2006). Farklı türde okullarda çalışan biyoloji öğretmenlerinin mesleki gelişim deneyim ve ihtiyaçları. Hacettepe Üniversitesi Eğitim Fakültesi Dergisi, 30, 174-183.

Patton, M.Q. (1990). Qualitative evaluation and research methods. USA: Sage. Pishghadam, R. ve Pourali, S. (2011). Metaphorical analysis of Iranian MA Students' beliefs: A qualitative study. Higher Education Studies, 1 (1), 27-37.

Plotz, T. ve Hollenthoner, F. (2019).Replicating a study about children's drawings concerning radiation. Multidisciplinary Journal for Education, Social and Technological Sciences, 6 (1), 71-88.

Saban, A. (2004). Giriş düzeyindeki sınıf öğretmeni adaylarının "öğretmen" kavramına ilişkin ileri sürdükleri metaforlar. Türk Ĕ̆gitim Bilimleri Dergisi. 2(2), 131-155.

Salman, Y. (2003). Dilin düşevreni: Eğretileme. Kitaplık, 65, 53-54.

Sanchez, A., Barreiro, J.M. ve Maojo, V. (2000). Design of virtual reality systems for education: A cognitive approach. Education and Information Technologies, 5(4), 345-362.

Shuell, T. J. (1990). Teaching and learning as problem solving. Theory into Practice, 29(2), 102-108.

Ural, E., ve Başaran, U.A.R. (2018).Öğretmen adaylarının fen laboratuvarı kavramına ilişkin metaforik algıları. Eğitim Kuram ve Uygulama Araştırmaları Dergisi, 4(3), 50-64.

Türk Dil Kurumu (2018). http://www.tdk.gov.tr, 30.09.2018 tarihinde erişildi.

White, R. ve Gunstone, R. (2000). Probing understanding. London: The Falmer Press.

Yapıcı, İ.Ü. (2015). Lise öğrencilerinin biyoloji kavramına ilişkin metaforik algiları. Elektronik Sosyal Bilimler Dergisi, 14(55), 139-147.

Yıldırım, A. ve Şimşek, H. (2016). Sosyal bilimlerde nitel araştırma yöntemleri. Ankara: Seçkin Yayıncılık. 
Yücel Cengiz, İ. ve Ekici, G. (2016). Biyoloji öğretmen adaylarının laboratuvar kavramına ilişkin görsel imajları. Eğitim ve Öğretim Araştırmaları Dergisi, 5 (3), 164-177.

\section{Kaynakça Bilgisi / Citation Information}

Cengiz, İ. Y. ve Ekici, G. (2019). Biyoloji öğretmen adaylarının biyoloji eğitimi laboratuvar dersine ilişkin metaforik algılarının incelenmesi. OPUS-Uluslararası Toplum Araştırmaları Dergisi, 11(18), 12181258. DOI: $10.26466 /$ opus. 538351 